\title{
Silicon dioxide-nanoparticle nutrition mitigates salinity in gerbera by modulating ion accumulation and antioxidants
}

\author{
Hanifeh Seyed Hajizadeh ${ }^{1, *}$, Mahsa Asadi ${ }^{1}$, Seyed Morteza Zahedi', \\ Nikoo Hamzehpour ${ }^{2}$, Farzad Rasouli', Murat Helvact ${ }^{3}$, Turgut Alas ${ }^{3}$
}

\footnotetext{
${ }^{1}$ Department of Horticultural Science, Faculty of Agriculture, University of Maragheh, Maragheh 55136-553, Iran

${ }^{2}$ Department of Soil Science and Engineering, Faculty of Agriculture, University of Maragheh, Maragheh 55136-553, Iran

${ }^{3}$ Faculty of Agricultural Sciences and Technologies, European University of Lefke, Lefke, Northern Cyprus, via Mersin 10, Turkey
}

\begin{abstract}
This work aimed to investigate the interaction between salt stress and the application of silicon dioxide-nanoparticles. In this study, gerbera plants grown in soilless culture were supplied with nutrient solutions with different $\mathrm{NaCl}$ concentrations $(0,5,10,20$ and $30 \mathrm{mM})$ in combination with $\mathrm{SiO}_{2}-\mathrm{NPs}$ spray $\left(0,25\right.$ and $\left.50 \mathrm{mg} \cdot \mathrm{L}^{-1}\right)$. Exposure of gerbera to salinity increased sodium concentration but decreased potassium and calcium concentrations in leaf as well as stem length/ diameter, fresh/dry weight, leaf/flower number, flower diameter and leaf area. It also increased the activities of antioxidant enzymes and electrolyte leakage. Results indicated that $\mathrm{SiO}_{2}-\mathrm{NPs}$ could improve growth, biochemical and physiological traits. It increased stem thickness but slightly affected stem length. Flower diameter was not affected by salinity rates up to $10 \mathrm{mM}$ of $\mathrm{NaCl}$. However, a significant difference was observed between controls and plants treated with $30 \mathrm{mM}$ of $\mathrm{NaCl}$. Salinity increased the electrolyte leakage (32.5\%), malondialdehyde (83.8\%), hydrogen peroxide (113.5\%), and the antioxidant enzyme activities such as ascorbate peroxidase (3.4-fold) and guaiacol peroxidase (6-fold) where $\mathrm{SiO}_{2}-\mathrm{NPs}$ activated them more, except for superoxide dismutase. Under salinity $(30 \mathrm{mM})$, the increase in $\mathrm{SiO}_{2}-\mathrm{NPs}_{\text {(especially at }}$ $\left.25 \mathrm{mg} \cdot \mathrm{L}^{-1}\right)$ led to the increase in the uptake of $\mathrm{Ca}^{2+}(25.3 \%)$ as well as $\mathrm{K}^{+}(27.1 \%)$ and decreased absorption of $\mathrm{Na}^{+}(6.3 \%)$. $\mathrm{SiO}_{2}-\mathrm{NPs}$ has potential in improving salinity tolerance in gerbera. It seems that the sensitivity threshold of gerbera to the salinity was $10 \mathrm{mM}$ and the use of $\mathrm{SiO}_{2}$-NPs is also effective in non-saline conditions.
\end{abstract}

Keywords: antioxidant defense, biostimulants, elemental status, nano- $\mathrm{SiO}_{2}$, salt stress

\section{Abbreviations:}

APX, ascorbate peroxidase; GPX, guaiacol peroxidase; MDA, malondialdehyde; PVPP, polyvinylpolypyrrolidone; $\mathrm{SiO}_{2}$ $\mathrm{NPs}, \mathrm{SiO}_{2}$ nano particles; SOD, superoxide dismutase; TBA, 2-thiobarbituric acid; TCA, trichloroacetic acid.

\section{INTRODUCTION}

Gerbera is widely used in cut flower industry and a well-known cut flower grown throughout the world in a variety of climatic conditions (Shafiullah Prodhan et al., 2017). Gerbera is the fifth ornamental plant, which is mostly used as cut flower after rose, carnation, chrysanthemum and tulip (National Garden Bureau). Due to colour variation, size of flower, having long vase life and wide adoptability for culture (Kulkarni et al., 2017), gerbera is a flower of choice for cultivation in greenhouse condition in many countries. 
Water scarcity and environmental pollution have led to an increase in the use of low-quality water for irrigation, especially improved wastewater and salty water (Shani and Dudley, 2001). Water for irrigation, both in terms of quality and quantity, remains a significant unresolved problem in agricultural production. On the other hand, salinity is the most significant qualitative characteristic of water resources (Brown et al., 2002) especially under hydroponic systems. Along with improper irrigation and chemical fertilisation in plants in soilless cultures, inadequate drainage and reduced root biomass can lead to salt accumulation in the rizosphere (Sonneveld et al., 2000). As a result, encountering the negative effects of salinity is critical where the production of cut flowers is performed under greenhouse condition, especially in hydroponic cultures. Salts in the soil, such as chloride and sodium sulphates, affect the growth of plants by changing the morphology, anatomy and physiology of plant (Saravanavel et al., 2011). Furthermore, salt stress reduced crop growth and productivity in sensitive varieties due to the negative effects on biomass, mineral components, hydraulic balance and carbon assimilation (Lauchli and Grattan, 2007). Many projects have been carried out on the effect of salt stress on gerbera (Paradiso, 2003; Akat et al., 2009; Ganege Don et al., 2010; Carmassi et al., 2013), and it has been demonstrated that the heist threshold of salinity without any reduction in yield of substrate-grown gerbera is 1.5 to $2.8 \mathrm{dS} \cdot \mathrm{m}^{-1}$ (Gómez Bellot et al., 2018).

Biostimulants contain different varieties of compounds, substances and microorganisms that are applied to plants or soil to restore crop vigour, yield, quality and abiotic stress tolerance (Hajizadeh et al., 2019). Recently, silicon compounds are increasingly used as a biostimulants in hydroponic nutrient solutions (Laane, 2018). It is known that silicon is an effective element for plant growth and development (Siddiqui et al., 2015). Several studies have indicated that silicon can act either as an essential or as a nonessential element depending on the plant variety. For example, for Equisetaceae family, silicon is essential (Epstein, 1994), but silicon may also help other plants in better adapting to different environmental stresses (Luyckx et al., 2017). There is a lot of literature about the beneficial effects of silicon on growth, yield and quality of fruits such as strawberry (Wang and Galetta, 1998) and also some of ornamentals including gerbera (Savvas et al., 2002), sun flower (Conceiḉao et al., 2019), Rosa hybrida (Savvas et al., 2007) and Zinnia elegans (Kamenidou et al., 2010). For example, spray with silicon compounds in marguerite daisy (Argyranthemum frutescens), strawflower (Xerochysum bracteatum), African daisy (Osteospermum ecklonis) and guara (Guara lindheimeri) increased the number of lateral shoots, bud and flower number and/or inflorescence number (Wróblewska and Dębicz, 2011).

Beneficial nanoparticles (NPs) in agricultural applications are currently interesting field of research
(Prasad et al., 2017; Zahedi et al., 2020a). Interactions of nanoparticles with plants cause many morphophysiological alterations, which are related to the particle properties. It has been demonstrated that spraying of SiNPs on plants increases the growth and development of plant by increasing proline accumulation, free amino acids, nutrient content, activity of antioxidative enzymes, gas exchange and photosynthetic apparatus efficiency (Kalteh et al., 2014). As the majority of cut flower production occurs in greenhouses and there is a risk of inverse effects of increased salinity on plant production and cut flower quality, therefore, it is important to specify the effects of several salt concentrations on plant growth, efficiency and quality in order to determine the tolerance threshold of each plant. Several researches suggested that addition of silicon to the nutritional solution is an effective alternative to combat the negative symptoms of salinity in plants (Jamali and Rahemi, 2011; Carvalho-Zanao et al., 2012; Jana and Jeong, 2014). In addition, it was observed that the $\mathrm{SiO}_{2}$ nano particles were different from their bulk form in their physical and chemical characteristics (O'Farrell et al., 2006; Rastogi et al., 2019). Today, hydroponic cultivation technology is widely used in flower and ornamental plants around the world. Since salinity control of nutrients is a constant problem and costly in hydroponic cultivation, and the scarcity of fresh water necessitates the use of different sources of water such as wells, effluents and recycled water. Therefore, the present work was subjected to evaluate the effects of different levels of salinity along with different levels of $\mathrm{SiO}_{2}$-NPs on gerbera (Gerbera $\times$ jamesonii $\mathrm{H}$. Bol cv. Terra Kalina) quality and nutritional uptake as well as antioxidative defense mechanism under hydroponic culture.

\section{MATERIALS AND METHODS}

\section{Plant materials, growth and treatments}

Gerbera (Gerbera × jamesonii H. Bol cv. 'Teera Kalina') plants were planted in 12 -L pots that contained $60 \%$ perlite and $40 \%$ cocopeat. The experiment was conducted at Fadak greenhouse in Maragheh $\left(46^{\circ} 16^{\prime} \mathrm{E}\right.$ and $37^{\circ} 23^{\prime} \mathrm{N}$, altitude $\left.1485 \mathrm{~m}\right)$, Iran. During the trial, the photoperiod of greenhouse was $14 / 10 \mathrm{~h}$ (light/dark), 22/18 $\pm 2{ }^{\circ} \mathrm{C}$ temperature (day/night) and $75 \pm 10 \%$ relative humidity. Plants were fed a Hogland nutrient solution containing macro and micro elements (Table 1) in irrigation water for 2 weeks until they were

Table 1. Composition and concentration of Macro and micro-elements used in modified Hogland solution.

\begin{tabular}{lllc}
\hline Macronutrient & $\mathrm{g} \cdot \mathrm{L}^{-1}$ & Micronutrient & $\mathrm{mg} \cdot \mathrm{L}^{-1}$ \\
\hline $\mathrm{Ca}\left(\mathrm{NO}_{3}\right)_{2} \cdot 4 \mathrm{H}_{2} \mathrm{O}$ & 0.47 & $\mathrm{H}_{3} \mathrm{BO}_{3}$ & 2.86 \\
$\mathrm{KNO}_{3}$ & 0.3 & $\mathrm{MnCl}_{2} \cdot 4 \mathrm{H}_{2} \mathrm{O}$ & 1.81 \\
$\mathrm{MgSO}_{4} \cdot 7 \mathrm{H}_{2} \mathrm{O}$ & 0.25 & $\mathrm{ZnSO}_{4} \cdot 7 \mathrm{H}_{2} \mathrm{O}$ & 0.22 \\
$\mathrm{NH}_{4} \mathrm{H}_{2} \mathrm{PO}_{4}$ & 0.06 & $\mathrm{Na}_{2} \mathrm{MOO}_{4} \cdot 2 \mathrm{H}_{2} \mathrm{O}$ & 0.02 \\
Iron $(\mathrm{Fe}-$ EDTA) & 0.1 & $\mathrm{CuSO}_{4} \cdot 5 \mathrm{H}_{2} \mathrm{O}$ & 0.08 \\
\hline
\end{tabular}




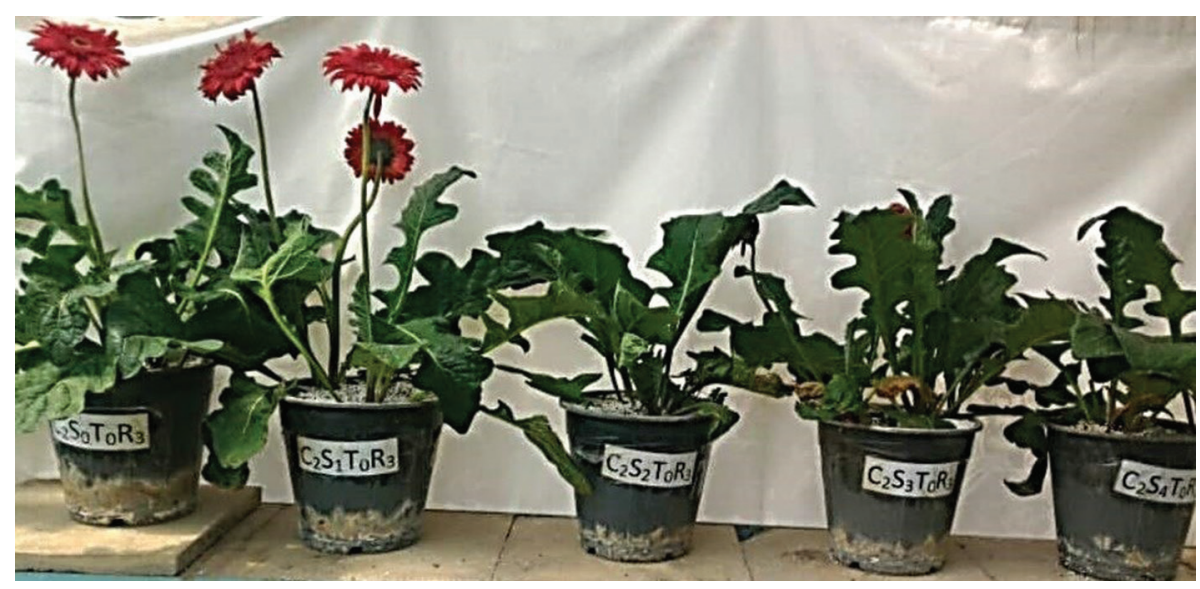

Figure 1. Gerbera cv. 'Teera Kalina' under different salinity levels $[\mathrm{S} 0=0 \mathrm{mM}$ (control), $\mathrm{S} 1=5 \mathrm{mM}, \mathrm{S} 2=10 \mathrm{mM}$, $\mathrm{S} 3=20 \mathrm{mM}$ and $\mathrm{S} 4=30 \mathrm{mM}]$ sprayed with $25 \mathrm{mg} \cdot \mathrm{L}^{-1} \mathrm{SiO}_{2}-\mathrm{NPs}$.

fully grown. The $\mathrm{pH}$ of Hogland solution in the tanker was adjusted to 5.5-6 using sodium bicarbonate or sulphuric acid. Then, the salinity level of the nutrient solution was considered as the control $\left(\mathrm{S}_{0}=0 \mathrm{mM}\right)$ with four other concentrations as $5\left(\mathrm{~S}_{1}\right), 10\left(\mathrm{~S}_{2}\right), 20\left(\mathrm{~S}_{3}\right)$ and $30\left(\mathrm{~S}_{4}\right) \mathrm{mM} \mathrm{NaCl}$. Plants were manually irrigated with the salinity treatments at a rate of $400 \mathrm{~mL}$ per pot every other day. At the end of each week, pots were irrigated with tap water to prevent leaching and salt accumulation.

After 3 months and just before flowering, the upper surface of leaves of control and salt-treated plants were sprayed until full wetting (ca. $25 \mathrm{~mL} \cdot$ plant $^{-1}$ ) with solutions containing 0 (distilled water as mentioned $\left.\mathrm{C}_{0}\right), 25\left(\mathrm{C}_{1}\right)$ and $50\left(\mathrm{C}_{2}\right) \mathrm{mg} \cdot \mathrm{L}^{-1} \mathrm{SiO}_{2}$-NPs as illustrated in Figure 1. $\mathrm{SiO}_{2}-\mathrm{NPs}$ (size $<50 \mathrm{~nm}$ ) were prepared from Nanosany Corporation of nanomaterial company, Iran. The $\mathrm{SiO}_{2}-\mathrm{NPs}$ properties are illustrated in Table 2. The size and type of nanoparticles used were selected based on the positive results of previous experiments (Zahedi et al., 2020b); indeed, the smaller NPs can enter into plant cells easily (Hossain et al., 2015). In addition, the Transmission Electron Microscopy (TEM) and Scanning Electron Microscopy (SEM) images of mesoporous silica particles (sample NNV001) synthesised by Nanosany Corporation are illustrated in Figure 2. Then the effect of mentioned $\mathrm{SiO}_{2}$-NPs spray on vegetative and flowering factors of gerbera was evaluated, and their interactions from morphological, physiological, and nutritional aspects were identified.

\section{Morphological and physiological traits of plant in response to $\mathrm{SiO}_{2}-\mathrm{NPs}$ treatment under salinity}

\section{Morphological parameters}

Following the completion of the trial, the number of leaves and flowers in each plant was recorded. Flower stem height and diameter, flower diameter were measured by digital caliper. Also, for plant fresh and dry weight, plants were harvested from each pot at the end
Table 2. $\mathrm{SiO}_{2}-\mathrm{NPs}$ properties.

\begin{tabular}{ll}
\hline \multicolumn{2}{c}{$\mathrm{SiO}_{2}-\mathrm{NPs}$} \\
\hline Purity & $99+\%$ \\
APS & $20-30 \mathrm{~nm}$ \\
SSA & $180-600 \mathrm{~m}^{2} \cdot \mathrm{g}^{-1}$ \\
Colour & White \\
Morphology & Amorphous \\
True density & $2.4 \mathrm{~g} \cdot \mathrm{cm}^{-3}$ \\
\hline
\end{tabular}

APS, average particle size; SSA, specific surface area.

of the treatment cycle, cleaned using deionised water, and dried in a forced-air oven at $70^{\circ} \mathrm{C}$ for $48 \mathrm{~h}$. Then dry weight was measured using electronic precision balance (Sartorius, Basic, Germany). Total leaf area was measured with a Delta-T Image Analysis System (Delta-T, LTD, Cambridge, UK).

\section{Membrane stability index (MSI)}

For measuring the stability of cell membrane, fresh leaf samples were cut into small discs with equal size. The weight of the samples were recorded, and $10 \mathrm{~mL}$ of $\mathrm{ddH}_{2} \mathrm{O}_{2}$ was added to test tubes. The tubes were incubated in a water bath at $40^{\circ} \mathrm{C}$ for $30 \mathrm{~min}$, and the electrical conductivity (C) of the samples was measured by using a conductivity bridge. Then leaf samples were transferred to other tubes and incubated in the boiling water bath at $100^{\circ} \mathrm{C}$ for $15 \mathrm{~min}$ and the second electrical conductivity of samples were measured as mentioned before. Then the amount of membrane stability was calculated and showed as percentage (Premachandra et al., 1990) by the following equation:

$\mathrm{MSI}=[1-(\mathrm{C} 1 / \mathrm{C} 2)] \times 100$

where $\mathrm{C} 1$ and $\mathrm{C} 2$ were $\mathrm{EC}$ at 40 and $100^{\circ} \mathrm{C}$, respectively.

\section{Electrolyte leakage (EL) percentage}

To identify cell membrane permeability, it is usually used of measuring the amount of electrolyte leakage according to Lutts et al. (1996). 

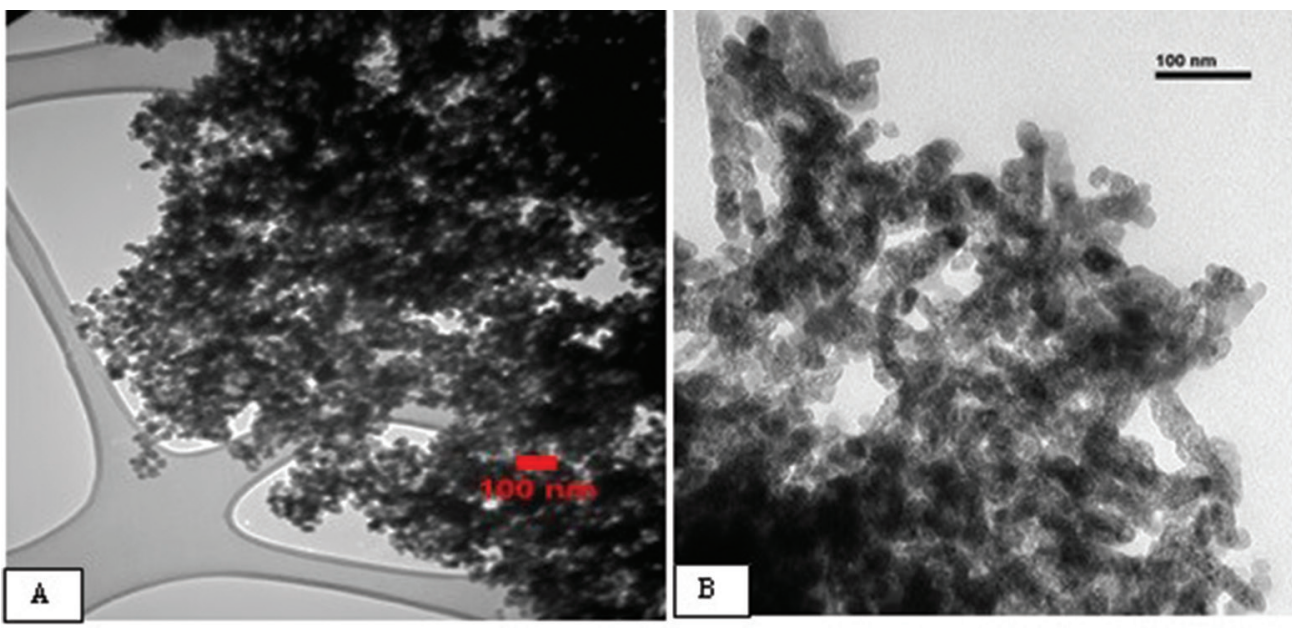

Figure 2. TEM (A) and SEM (B) images of $\mathrm{SiO}_{2}$-NPs.

\section{Leaf relative water contents ( $R W C$ )}

The RWC of leaves was identified in the fresh leaf of plant. Fresh weight of leaf samples were measured (FW) and then were digging in $\mathrm{ddH}_{2} \mathrm{O}_{2}$. After $2 \mathrm{~h}$, the leaves were taken out of the water; the surface water was removed and again measured as turgid weight (TW). Then the samples were dried at $70^{\circ} \mathrm{C}$ in an oven to constant weight (DW). RWC of leaves was estimated according to the following equation (Turner, 1981):

$\mathrm{RWC}(\%)=[(\mathrm{FW}-\mathrm{DW}) /(\mathrm{TW}-\mathrm{DW})] \times 100$

\section{SPAD Measurements}

The SPAD value was recorded by a hand-held chlorophyll meter (SPAD-502, Konika Minolta, Japan).

\section{Biochemical analysis and antioxidant enzyme activities of plants in response to $\mathrm{SiO}_{2}-\mathrm{NPS}$ treatment under salinity}

\section{Proline determination}

For measuring the amount of proline, $0.2 \mathrm{~g}$ fresh weight of leaf was homogenised in $2 \mathrm{~mL}$ of $3 \%$ aqueous sulfosalicylic acid and centrifuged at 10,000 rpm for $30 \mathrm{~min}$. After decanting the supernatant, pellet was washed with $3 \%$ aqueous sulfosalicylic acid. The supernatants were pooled, and the proline content was estimated using ninhydrin reagent and toluene extraction (Bates et al., 1973). For each determination, this method was calibrated with standard solutions of proline within the certain range of the method (0-39 $\left.\mu \mathrm{g} \cdot \mathrm{mL}^{-1}\right)$.

\section{Protein determination}

Determination of protein was done using the Bradford procedure (Bradford, 1976) and a standard curve draw according to certain amounts of bovine serum albumin was used. Briefly, Coomassie blue is a reagent that reacts with basic amino acid residues mostly with arginine in response to different protein concentrations.
After the plants had been treated, $100 \mathrm{mg}$ of the dried leaf was placed in a test tube with $2 \mathrm{~mL}$ of $50 \mathrm{mM}$ potassium phosphate buffer at $\mathrm{pH} 7.0$ and centrifuged at 7,000-12,000 rpm. The supernatant was removed and centrifuged at $3,000 \mathrm{rpm}$ for $15 \mathrm{~min}$ at $4^{\circ} \mathrm{C}$. Samples were diluted 1:100 and the amount of absorption was recorded at $595 \mathrm{~nm}$ by spectrophotometer and recorded as $\mathrm{mg} \cdot \mathrm{g}^{-1} \mathrm{FW}$.

\section{Malondialdehyde (MDA) determination}

Determination of malondialdehyde was done using 2-thiobarbituric acid (TBA) reactive metabolites (Zhang et al., 2007). In this method, $1.5 \mathrm{~mL}$ extract was homogenised in $2.5 \mathrm{~mL}$ of $5 \%$ TBA made in $5 \%$ trichloroacetic acid (TCA). The solution was heated to $95^{\circ} \mathrm{C}$ for $15 \mathrm{~min}$ and then quickly cooled on ice. The samples were centrifuged for $10 \mathrm{~min}$ at $5,000 \mathrm{rpm}$, and the amount of supernatant absorption was measured at $532 \mathrm{~nm}$ using spectrophotometer. For correcting the non-specific turbidity, the absorbance value measured at $600 \mathrm{~nm}$ subtracted from the first amount of absorption at $532 \mathrm{~nm}$. MDA was recorded as $\mathrm{nmol} \cdot \mathrm{g}^{-1} \mathrm{FW}$.

\section{Hydrogen peroxide $\left(\mathrm{H}_{2} \mathrm{O}_{2}\right)$ determination}

Determination of $\mathrm{H}_{2} \mathrm{O}_{2}$ in leaves was done by the established protocol of Liu et al. (2014). Briefly, $0.5 \mathrm{~g}$ of leaf sample was homogenised in liquid nitrogen and a potassium phosphate buffer (KPB) (pH 6.8). Sample extractions were centrifuged at 7,000 rpm for $25 \mathrm{~min}$ at $4^{\circ} \mathrm{C}$. A $100-\mu \mathrm{L}$ aliquot of the supernatant was added to $1 \mathrm{~mL}$ of xylenol solution, mixed, and set aside for $30 \mathrm{~min}$ to rest. Then, according to the purity of the colour, which is a direct representation of the amount of $\mathrm{H}_{2} \mathrm{O}_{2}$ in the sample, was recorded by spectrophotometer (Shimadzu, Japan) at $560 \mathrm{~nm}$ and recorded in terms of $\mu \mathrm{mol} \cdot \mathrm{g}^{-1} \mathrm{FW}$.

\section{Antioxidant enzyme activities}

To prepare the extraction for measuring antioxidant enzyme activities, $1 \mathrm{~g}$ of fresh leaf samples were 
weighted and immediately homogenised in $5 \mathrm{~mL}$

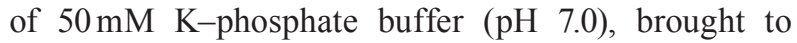
$5 \mathrm{mM} \mathrm{Na}-$ ascorbate and $0.2 \mathrm{mM}$ EDTA by adding the concentrated stocks. The homogenised sample was centrifuged at $10,000 \mathrm{rpm}$ for $15 \mathrm{~min}$ at $4^{\circ} \mathrm{C}$. Finally, the resulted supernatant was used for measuring the activity of antioxidative enzymes. The extraction was carried out at $4^{\circ} \mathrm{C}$.

\section{Guaiacol peroxidase (GPX) determination}

The activity of GPX was evaluated by screening the increasing trend in the absorption at $470 \mathrm{~nm}$ $\left(\varepsilon=26.6 \mathrm{mM}^{-1} \mathrm{~cm}^{-1}\right)$ during polymerisation of guaiacol. One unit of enzyme activity was described as the amount of enzyme producing $1 \mu \mathrm{mol}$ of tetraguaiacol per min at $25^{\circ} \mathrm{C}$.

\section{Ascorbate peroxidase (APX) determination}

For measuring the amount of ascorbate peroxidase, the method of Yoshimura et al. (2000) was used. In the mentioned procedure, the reaction solution consists of phosphate buffer $(250 \mu \mathrm{L}), 1 \mathrm{mM}$ ascorbate $(250$ $\mu \mathrm{L}), 0.4 \mu \mathrm{M}$ EDTA $(250 \mu \mathrm{L}), 190 \mu \mathrm{L} \mathrm{ddH}_{2} \mathrm{O}_{2}, 10 \mathrm{mM}$ transoxide $(10 \mu \mathrm{L})$, and $50 \mu \mathrm{L}$ supernatant. Enzyme activity was recorded as an amount of supernatant absorption at $290 \mathrm{~nm}$ for $1 \mathrm{~min}$. To estimate the correct amount of enzyme activity, an extinction coefficient of $2.8 \mathrm{mM}^{-1} \mathrm{~cm}^{-1}$ for $1 \mathrm{~min}$ was applied.

\section{Superoxide dismutase (SOD) determination}

The activity of SOD was assayed by the established method of Beauchamp and Fridovich (1971), which is based on the inhibition of the photochemical reduction of nitro blue tetrazolium (NBT). In this method, $0.5 \mathrm{~g}$ of leaf samples were homogenised in $5 \mathrm{~mL}$ of potassium phosphate buffer ( $\mathrm{pH} 7)$, mixed with EDTA ( $\mathrm{pH}$ 7.8), and $1 \%$ polyvinylpolypyrrolidone (PVPP). The resulted extraction was centrifuged at 7,000 rpm for $10 \mathrm{~min}$. The reaction mixture consists of $0.1 \mathrm{mM}$ EDTA, $50 \mathrm{mM}$ buffer phosphate, $13 \mathrm{mM}$ methionine and $75 \mu \mathrm{M}$ NBT and $2 \mathrm{mM}$ riboflavin (totally $1 \mathrm{~mL}$ ) and $100 \mu \mathrm{L}$ of enzyme extraction. The mentioned mixture was then placed under a $20-\mathrm{W}$ fluorescent lamp for $15 \mathrm{~min}$, and the samples in the tubes were covered with a black cloth. At the end of the reaction, the amount of absorption was recorded at $560 \mathrm{~nm}$ by spectrophotometer.

\section{Nutrient concentrations of $\mathrm{Na}^{+}, \mathrm{Ca}^{2+}$ and $\mathrm{K}^{+}$of plants in response to $\mathrm{SiO}_{2}-\mathrm{NPs}$ treatment under salinity}

Powder of the oven-dried leaf samples $(0.5 \mathrm{~g})$ was digested in a solution of nitric acid and perchloric acid (2:1; V/V; Malavolta et al., 1997). The concentration of $\mathrm{Na}^{+}$and $\mathrm{K}^{+}$was quantified using flame photometry (Jeneway, model PFP7) against $\mathrm{Na}^{+}$and $\mathrm{K}^{+}$standards curve of certain concentrations, according to the method of Ren et al. (2005). $\mathrm{Ca}^{2+}$ was measured by titration with EDTA and recorded as $\mathrm{g} \cdot 100 \mathrm{~g}^{-1} \mathrm{FW}$.

\section{Statistical analysis}

Data analyzed by ANOVA software (SAS, version 9.4), and the difference between treatments was determined by the Duncan Multiple Range at $p<0.05$. The trial was carried out as a factorial experiment in a completely randomised design (CRD), with three repetitions and each repetition includes two plants.

\section{RESULTS AND DISCUSSION}

\section{Morphological and physiological parameters of gerbera plants in response to $\mathrm{SiO}_{2}-\mathrm{NPs}$ treatment with and without salinity}

The number of leaves and flowers on gerbera plants was significantly decreased in salt-treated plants compared to control. Among different salinity levels, the highest salinity $(30 \mathrm{mM} \mathrm{NaCl})$ exhibited a profound reduction of 30 and $55 \%$ in the number of leaves and flowers on gerbera plants, respectively, versus the control (Table 3).

The highest number of flowers was obtained from S0 (non-saline) which was sprayed with 25 and $50 \mathrm{mg} \cdot \mathrm{L}^{-1}$ of $\mathrm{SiO}_{2}-\mathrm{NPs}$ (1.87 and 1.73, respectively) while $\mathrm{S} 5(30 \mathrm{mM} \mathrm{NaCl})$ without $\mathrm{SiO}_{2}$-NPs spray had the least number of flowers (0.7). The highest leaf number belonged to $10 \mathrm{mM} \mathrm{NaCl}$ along with $25 \mathrm{mg} \cdot \mathrm{L}^{-1}$ $\mathrm{SiO}_{2}$-NPs spray, while the lowest leaf number was observed in $30 \mathrm{mM} \mathrm{NaCl}$ without $\mathrm{SiO}_{2}$-NPs spray (6.5) (Table 3). Plant shoot weight, especially dry weight, was more affected by salinity. Increased salinity levels resulted in decrease in fresh/dry weight of plant with the maximum and minimum weight ratios of 1.2 and 1.9, respectively. The highest shoot fresh/dry weight was observed in control, and it was not significantly different with $\mathrm{S}_{0} \mathrm{C}_{1}$ and $\mathrm{S}_{0} \mathrm{C}_{2}$ treatments. The lowest fresh/dry weight belonged to the $\mathrm{S}_{5} \mathrm{C}_{0}$ treatment $(30 \mathrm{mM}$ $\mathrm{NaCl}$, without $\left.\mathrm{SiO}_{2}-\mathrm{NPs}\right)$. However, in $\mathrm{S}_{5} \mathrm{C}_{2}$ treatment (30 $\left.\mathrm{mM} \mathrm{NaCl}+25 \mathrm{mg} \cdot \mathrm{L}^{-1} \mathrm{SiO}_{2}-\mathrm{NPs}\right)$, fresh weight significantly increased in comparison to $\mathrm{S}_{5} \mathrm{C}_{0}$. Thus, it could be concluded that the modifying effects of $\mathrm{SiO}_{2}$ NPs reduced the harmful effects of salinity. Results show that stem length was not affected by salinity levels up to $20 \mathrm{mM}$ significantly. However, in $30 \mathrm{mM}$ salinity level without the $\mathrm{SiO}_{2}$-NPs application, the shortest stem length was measured $(6.66 \mathrm{~cm}$ vs $19.00 \mathrm{~cm}$ in control). Flower diameter was less affected because no significant difference was observed between all treated plants just compared to controls. Also, salinity-treated plants sprayed with $25 \mathrm{mg} \cdot \mathrm{L}^{-1}$ of $\mathrm{SiO}_{2}-\mathrm{NP}$ had the most flower diameter. Stem diameter was more affected by salinity as the control sprayed with $25 \mathrm{mg} \cdot \mathrm{L}^{-1} \mathrm{SiO}_{2}-\mathrm{NP}$ had the most amount of diameter $(0.6 \mathrm{~mm})$ compared with $30 \mathrm{mM}$ of salinity $(0.13 \mathrm{~mm})$. Savvas et al. (2002) reported that adding $\mathrm{Si}$ to the nutrient solution of gerbera enhanced the stem diameter of the flowers but did not affect the stem length. Increase in salinity levels from 0 up to $30 \mathrm{mM}$ caused a significant reduction in flower number of plant and fresh weight of the flowers approximately by 55 and $18 \%$, respectively, regardless 
Table 3. Effect of $\mathrm{SiO}_{2}$-NPs and salt stress on morphological parameters of gerbera cv. 'Teera Kalina'.

\begin{tabular}{|c|c|c|c|c|c|}
\hline \multicolumn{2}{|l|}{ Treatments } & \multirow[t]{2}{*}{ Leaf No. } & \multirow[t]{2}{*}{ Flower No. } & \multirow{2}{*}{$\begin{array}{l}\text { Plant fresh weight } \\
(\mathrm{g})\end{array}$} & \multirow{2}{*}{$\begin{array}{l}\text { Plant dry weight } \\
(\mathrm{g})\end{array}$} \\
\hline Salinity (mM) & $\mathrm{SiO}_{2}-\mathrm{NPs}\left(\mathrm{mg} \cdot \mathrm{L}^{-1}\right)$ & & & & \\
\hline \multirow[t]{3}{*}{ Control } & 0 & $9.33 \pm 0.60 \mathrm{ab}$ & $1.56 \pm 0.20 \mathrm{abc}$ & $79.33 \pm 0.25 \mathrm{a}$ & $29.33 \pm 0.25 \mathrm{a}$ \\
\hline & 25 & $9.33 \pm 0.50 \mathrm{ab}$ & $1.86 \pm 0.03 \mathrm{a}$ & $79.93 \pm 0.05 \mathrm{a}$ & $29.46 \pm 0.45 \mathrm{a}$ \\
\hline & 50 & $9.00 \pm 0.50 \mathrm{abc}$ & $1.73 \pm 0.03 \mathrm{a}$ & $80.16 \pm 0.60 \mathrm{a}$ & $24.50 \pm 1.80 \mathrm{bc}$ \\
\hline \multirow[t]{3}{*}{5} & 0 & $8.83 \pm 0.70 \mathrm{abc}$ & $1.52 \pm 0.20 \mathrm{abc}$ & $77.73 \pm 0.15 \mathrm{abc}$ & $3.12 \pm 1.70 \mathrm{f}$ \\
\hline & 25 & $9.16 \pm 0.90 \mathrm{ab}$ & $1.86 \pm 0.03 \mathrm{a}$ & $78.90 \pm 0.25 \mathrm{ab}$ & $25.90 \pm 1.10 \mathrm{ab}$ \\
\hline & 50 & $8.83 \pm 0.50 \mathrm{abc}$ & $1.70 \pm 0.05 \mathrm{ab}$ & $77.23 \pm 0.20 \mathrm{abcd}$ & $24.33 \pm 1.30 \mathrm{bc}$ \\
\hline \multirow[t]{3}{*}{10} & 0 & $7.83 \pm 0.40 \mathrm{abc}$ & $1.21 \pm 0.10 \mathrm{cde}$ & $73.93 \pm 0.75$ bcdef & $18.26 \pm 2.10 \mathrm{de}$ \\
\hline & 25 & $9.66 \pm 0.95 \mathrm{a}$ & $1.63 \pm 0.03 \mathrm{ab}$ & $75.96 \pm 0.60$ abcde & $21.16 \pm 0.90 \mathrm{~cd}$ \\
\hline & 50 & $8.16 \pm 0.35 \mathrm{abc}$ & $1.33 \pm 0.15 \mathrm{bcd}$ & $70.03 \pm 0.90$ ef & $18.63 \pm 0.30 \mathrm{de}$ \\
\hline \multirow[t]{3}{*}{20} & 0 & $7.16 \pm 0.30 \mathrm{abc}$ & $0.98 \pm 0.04 \mathrm{def}$ & $71.83 \pm 0.10 \mathrm{def}$ & $20.83 \pm 0.45 \mathrm{~cd}$ \\
\hline & 25 & $7.66 \pm 0.75 \mathrm{abc}$ & $1.20 \pm 0.10 \mathrm{cde}$ & $72.80 \pm 0.45 \mathrm{cdef}$ & $22.33 \pm 0.90 \mathrm{bcd}$ \\
\hline & 50 & $7.50 \pm 0.25 \mathrm{abc}$ & $1.00 \pm 0.08 \mathrm{def}$ & $71.03 \pm 0.40 \mathrm{ef}$ & $26.03 \pm 0.40 \mathrm{ab}$ \\
\hline \multirow[t]{3}{*}{30} & 0 & $6.50 \pm 0.60 \mathrm{c}$ & $0.70 \pm 0.05 \mathrm{f}$ & $64.93 \pm 0.90 \mathrm{~g}$ & $15.10 \pm 0.45 \mathrm{e}$ \\
\hline & 25 & $7.66 \pm 0.15 \mathrm{abc}$ & $0.90 \pm 0.05$ ef & $71.83 \pm 0.90 \mathrm{def}$ & $16.26 \pm 0.60 \mathrm{e}$ \\
\hline & 50 & $7.00 \pm 0.60 \mathrm{bc}$ & $0.73 \pm 0.03 \mathrm{f}$ & $69.10 \pm 0.50 \mathrm{fg}$ & $16.33 \pm 0.30 \mathrm{e}$ \\
\hline \multicolumn{2}{|l|}{ Treatments } & Stem length & Stem diameter & Flower diameter & Leaf area \\
\hline Salinity $(\mathrm{mM})$ & $\mathrm{SiO}_{2}-\mathrm{NPs}\left(\mathrm{mg} \cdot \mathrm{L}^{-1}\right)$ & $(\mathrm{cm})$ & $(\mathrm{mm})$ & $(\mathrm{cm})$ & $\left(\mathrm{cm}^{2}\right)$ \\
\hline \multirow[t]{3}{*}{ Control } & 0 & $19.00 \pm 1.20 \mathrm{a}$ & $0.56 \pm 0.03 \mathrm{ab}$ & $4.56 \pm 0.40 \mathrm{ab}$ & $228.67 \pm 1.85 \mathrm{~b}$ \\
\hline & 25 & $20.00 \pm 0.90 \mathrm{a}$ & $0.60 \pm 0.05 \mathrm{a}$ & $5.37 \pm 0.10 \mathrm{a}$ & $260.82 \pm 1.70 \mathrm{a}$ \\
\hline & 50 & $19.33 \pm 0.70 \mathrm{a}$ & $0.50 \pm 0.05 \mathrm{abc}$ & $5.36 \pm 0.25 \mathrm{ab}$ & $239.09 \pm 1.65 \mathrm{ab}$ \\
\hline \multirow[t]{3}{*}{5} & 0 & $14.33 \pm 0.90 \mathrm{ab}$ & $0.46 \pm 0.03 \mathrm{abcd}$ & $5.65 \pm 0.50 \mathrm{ab}$ & $176.03 \pm 1.70 \mathrm{c}$ \\
\hline & 25 & $19.66 \pm 0.90 \mathrm{a}$ & $0.46 \pm 0.03 \mathrm{abcd}$ & $6.04 \pm 0.15 \mathrm{a}$ & $213.08 \pm 1.50 \mathrm{c}$ \\
\hline & 50 & $18.33 \pm 0.85 \mathrm{a}$ & $0.43 \pm 0.03$ bcde & $5.31 \pm 0.10 \mathrm{ab}$ & $184.53 \pm 1.90 \mathrm{c}$ \\
\hline \multirow[t]{3}{*}{10} & 0 & $13.00 \pm 0.50 \mathrm{ab}$ & $0.33 \pm 0.03 \mathrm{defg}$ & $4.43 \pm 0.30 \mathrm{ab}$ & $136.91 \pm 1.50 \mathrm{~d}$ \\
\hline & 25 & $14.66 \pm 0.90 \mathrm{ab}$ & $0.36 \pm 0.03 \mathrm{cdef}$ & $5.29 \pm 0.50 \mathrm{ab}$ & $144.92 \pm 1.70 \mathrm{~d}$ \\
\hline & 50 & $13.66 \pm 0.75 \mathrm{ab}$ & $0.33 \pm 0.03 \mathrm{defg}$ & $4.85 \pm 0.07 \mathrm{ab}$ & $143.62 \pm 1.90 \mathrm{~d}$ \\
\hline \multirow[t]{3}{*}{20} & 0 & $11.66 \pm 0.90 \mathrm{ab}$ & $0.26 \pm 0.02 \mathrm{fghi}$ & $3.46 \pm 0.90 \mathrm{~b}$ & $90.41 \pm 2.20 \mathrm{ef}$ \\
\hline & 25 & $14.16 \pm 0.90 \mathrm{ab}$ & $0.30 \pm 0.05 \mathrm{efgh}$ & $5.08 \pm 0.40 \mathrm{ab}$ & $95.73 \pm 1.80 \mathrm{e}$ \\
\hline & 50 & $12.83 \pm 0.35 a b$ & $0.30 \pm 0.05 \mathrm{defg}$ & $4.50 \pm 0.90 \mathrm{ab}$ & $92.43 \pm 1.50 \mathrm{ef}$ \\
\hline \multirow[t]{3}{*}{30} & 0 & $6.66 \pm 0.90 b$ & $0.13 \pm 0.03 \mathrm{i}$ & $3.40 \pm 0.30 \mathrm{~b}$ & $65.74 \pm 1.75 \mathrm{f}$ \\
\hline & 25 & $12.33 \pm 0.30 \mathrm{ab}$ & $0.20 \pm 0.05 \mathrm{ghi}$ & $4.22 \pm 0.10 \mathrm{ab}$ & $82.20 \pm 1.40$ ef \\
\hline & 50 & $11.33 \pm 0.30 \mathrm{ab}$ & $0.16 \pm 0.03 \mathrm{hi}$ & $3.60 \pm 0.01 \mathrm{~b}$ & $77.90 \pm 0.85 \mathrm{ef}$ \\
\hline
\end{tabular}

Values represent means \pm standard errors of three independent replications $(n=3)$.

Different letters within the same column indicate significant differences at $p<0.05$ among the treatments, according to Duncan's multiple range tests.

of $\mathrm{SiO}_{2}$-NPs application. In controls, spraying gerbera plants with $\mathrm{SiO}_{2}$-NPs $\left(25 \mathrm{mg} \cdot \mathrm{L}^{-1}\right)$ significantly cause to increase in leaf area (14\%) compare to un-treated plants. These findings agree with the obtained results on Calendula (Bayat et al., 2013). According to the Munns (2002), inhibition of plant growth and development under salinity may either be because of reduction in water availability or sodium chloride toxicity. Leaf area index is one of the major factors in the growth of plants under salinity stress. As shown in Table 3, leaf areas decreased as the salinity level increased. Control plants sprayed with $25 \mathrm{mg} \cdot \mathrm{L}^{-1} \mathrm{SiO}_{2}$-NPs had the highest leaf area $\left(260.8 \mathrm{~cm}^{2}\right)$ compared to treated plants with $30 \mathrm{mM}$ salinity $\left(65.7 \mathrm{~cm}^{2}\right)$. Hence, the positive role of $\mathrm{SiO}_{2}-\mathrm{NPs}$ treatments in modification of the adverse effects of salinity is undeniable. In other words, silicon increases the stability of cell wall by forming a layer (Marschner, 2011). In addition, $\mathrm{SiO}_{2}$-NPs particles can better affect xylem humidity and water translocation through their larger surface area through which they can improve the water uptake and cell division and elongation in flowers. Savvas et al. (2002) reported that adding Si to nutrient solution resulted in the most amount of class I flowers and ticker flower stems in gerbera. In addition, Hwang et al. (2005) demonstrated that using potassium silicate enhanced the growth and quality of cut miniature rose 'Pinocchio' in a rock wool culture system.

Values of electrolyte leakage and MSI are used indirectly for showing the damage to cell membrane in salinity conditions (Ali et al., 2008). Increasing in salinity level cause to decrease in cell membrane stability (30\%) and subsequently increased in EL up to $83 \%$ as shown in Table 4 in controls and $30 \mathrm{mM}$ salinity treated ones. However, a beneficial effect $\mathrm{SiO}_{2}-\mathrm{NPs}$ in sustainability of cell walls is quite impressive especially at higher ranges of $10 \mathrm{mM}$ salinity. EL is inversely correlated with membrane stability. Using of $\mathrm{SiO}_{2}-\mathrm{NPs}$ at $50 \mathrm{mg} \cdot \mathrm{L}^{-1}$ only cause to 11.8 and $45.6 \%$ decrease and 
Table 4. Effect of $\mathrm{SiO}_{2}-\mathrm{NPs}$ and salt stress on physiological and biochemical traits of gerbera cv. 'Teera Kalina'.

\begin{tabular}{|c|c|c|c|c|}
\hline \multicolumn{2}{|l|}{ Treatments } & \multirow{2}{*}{$\begin{array}{l}\text { MSI } \\
(\%)\end{array}$} & \multirow[t]{2}{*}{ EL } & \multirow[t]{2}{*}{ RWC } \\
\hline Salinity (mM) & $\mathrm{SiO}_{2}-\mathrm{NPs}\left(\mathrm{mg} \cdot \mathrm{L}^{-1}\right)$ & & & \\
\hline \multirow[t]{3}{*}{ Control } & 0 & $93.13 \pm 0.10 \mathrm{a}$ & $32.92 \pm 0.90 \mathrm{fg}$ & $89.23 \pm 0.23 \mathrm{ab}$ \\
\hline & 25 & $75.08 \pm 0.95 \mathrm{~cd}$ & $31.52 \pm 0.72 \mathrm{~g}$ & $90.16 \pm 0.13 \mathrm{a}$ \\
\hline & 50 & $72.26 \pm 0.90 \mathrm{cde}$ & $31.73 \pm 0.44 \mathrm{~g}$ & $89.83 \pm 0.82 \mathrm{a}$ \\
\hline \multirow[t]{3}{*}{5} & 0 & $81.87 \pm 0.90 b$ & $36.41 \pm 0.01$ ef & $86.07 \pm 0.16 \mathrm{~cd}$ \\
\hline & 25 & $77.54 \pm 0.90 \mathrm{bc}$ & $34.07 \pm 0.02 \mathrm{fg}$ & $87.23 \pm 0.40 \mathrm{bc}$ \\
\hline & 50 & $70.78 \pm 0.95 \mathrm{defg}$ & $33.98 \pm 0.02 \mathrm{fg}$ & $85.56 \pm 0.61 \mathrm{~cd}$ \\
\hline \multirow[t]{3}{*}{10} & 0 & $71.46 \pm 0.70 \mathrm{defg}$ & $39.66 \pm 0.70 \mathrm{de}$ & $82.60 \pm 0.32$ ef \\
\hline & 25 & $69.22 \pm 0.20 \mathrm{efgh}$ & $35.75 \pm 0.30 \mathrm{f}$ & $84.63 \pm 0.31 \mathrm{de}$ \\
\hline & 50 & $71.61 \pm 0.80 \mathrm{def}$ & $39.59 \pm 0.90 \mathrm{de}$ & $81.73 \pm 0.90 \mathrm{f}$ \\
\hline \multirow[t]{3}{*}{20} & 0 & $68.86 \pm 0.35 \mathrm{efgh}$ & $51.44 \pm 0.75 \mathrm{~b}$ & $80.83 \pm 0.37 \mathrm{fg}$ \\
\hline & 25 & $66.41 \pm 0.30 \mathrm{efgh}$ & $45.70 \pm 0.90 \mathrm{c}$ & $82.46 \pm 0.75$ ef \\
\hline & 50 & $65.27 \pm 0.90 \mathrm{gh}$ & $41.50 \pm 0.70 \mathrm{~d}$ & $81.03 \pm 0.39 \mathrm{fg}$ \\
\hline \multirow[t]{3}{*}{30} & 0 & $65.59 \pm 0.90 \mathrm{fgh}$ & $60.41 \pm 0.40 \mathrm{a}$ & $67.60 \pm 0.24 \mathrm{i}$ \\
\hline & 25 & $63.49 \pm 0.70 \mathrm{~h}$ & $46.33 \pm 0.90 \mathrm{c}$ & $78.83 \pm 0.62 \mathrm{~g}$ \\
\hline & 50 & $63.73 \pm 0.45 \mathrm{~h}$ & $46.23 \pm 0.60 \mathrm{c}$ & $74.24 \pm 0.90 \mathrm{~h}$ \\
\hline \multicolumn{2}{|l|}{ Treatments } & \multirow[t]{2}{*}{ SPAD } & \multirow{2}{*}{$\begin{array}{c}\text { Proline } \\
\left(\mathrm{mmol} \cdot \mathrm{g}^{-1}\right)\end{array}$} & \multirow{2}{*}{$\begin{array}{c}\text { Protein } \\
\left(\mathrm{mg} \cdot \mathrm{g}^{-1} \mathrm{FW}\right)\end{array}$} \\
\hline Salinity (mM) & $\mathrm{SiO}_{2}-\mathrm{NPs}\left(\mathrm{mg} \cdot \mathrm{L}^{-1}\right)$ & & & \\
\hline \multirow[t]{3}{*}{ Control } & 0 & $76.40 \pm 0.19 \mathrm{ab}$ & $2.74 \pm 0.24 \mathrm{e}$ & $0.24 \pm 0.009 \mathrm{a}$ \\
\hline & 25 & $77.43 \pm 0.20 \mathrm{a}$ & $4.52 \pm 0.34 \mathrm{e}$ & $0.25 \pm 0.002 \mathrm{a}$ \\
\hline & 50 & $78.40 \pm 0.14 \mathrm{a}$ & $4.40 \pm 0.50 \mathrm{e}$ & $0.25 \pm 0.005 \mathrm{a}$ \\
\hline \multirow[t]{3}{*}{5} & 0 & $74.63 \pm 0.40 \mathrm{ab}$ & $3.63 \pm 0.45 \mathrm{e}$ & $0.23 \pm 0.007 \mathrm{ab}$ \\
\hline & 25 & $75.90 \pm 0.50 \mathrm{ab}$ & $7.30 \pm 0.45 \mathrm{e}$ & $0.25 \pm 0.010 \mathrm{a}$ \\
\hline & 50 & $76.23 \pm 0.11 \mathrm{ab}$ & $7.51 \pm 0.50 \mathrm{e}$ & $0.22 \pm 0.004 b c$ \\
\hline \multirow[t]{3}{*}{10} & 0 & $65.93 \pm 0.94 \mathrm{abc}$ & $13.27 \pm 0.43 \mathrm{~d}$ & $0.18 \pm 0.002 \mathrm{def}$ \\
\hline & 25 & $70.30 \pm 0.86 \mathrm{abc}$ & $15.81 \pm 0.11 \mathrm{~d}$ & $0.21 \pm 0.002 \mathrm{c}$ \\
\hline & 50 & $66.93 \pm 0.70 \mathrm{abc}$ & $13.88 \pm 0.07 \mathrm{~d}$ & $0.19 \pm 0.009 \mathrm{cde}$ \\
\hline \multirow[t]{3}{*}{20} & 0 & $65.23 \pm 0.21 \mathrm{abc}$ & $31.41 \pm 0.90 \mathrm{ab}$ & $0.17 \pm 0.007$ ef \\
\hline & 25 & $63.06 \pm 0.22 \mathrm{bc}$ & $29.95 \pm 0.90 \mathrm{~b}$ & $0.20 \pm 0.002 \mathrm{~cd}$ \\
\hline & 50 & $58.13 \pm 0.12 \mathrm{~cd}$ & $23.44 \pm 0.873 \mathrm{c}$ & $0.20 \pm 0.005 \mathrm{~cd}$ \\
\hline \multirow[t]{3}{*}{30} & 0 & $46.43 \pm 0.91 \mathrm{~d}$ & $36.49 \pm 0.01 \mathrm{a}$ & $0.11 \pm 0.004 \mathrm{~h}$ \\
\hline & 25 & $56.90 \pm 0.82 \mathrm{~cd}$ & $35.56 \pm 0.20 \mathrm{a}$ & $0.14 \pm 0.002 \mathrm{~g}$ \\
\hline & 50 & $56.36 \pm 0.72 \mathrm{~cd}$ & $32.41 \pm 0.39 \mathrm{ab}$ & $0.16 \pm 0.002 \mathrm{fg}$ \\
\hline
\end{tabular}

Values represent means \pm standard errors of three independent replications $(n=3)$.

Different letters within the same column indicate significant differences at $p<0.05$ among the treatments, according to Duncan's multiple range test.

EL, electrolyte leakage; MSI, membrane stability index; RWC, relative water contents.

increase in MSI and EL at $30 \mathrm{mM}$ salinity. The effect of salinity on MSI and electrolyte leakage could be related to damage of plasma membrane, which is caused by reactive oxygen species. Probably, the most suitable factor for monitoring plant status in water deficiency can be the measurement of leaf relative water content as a physiological parameter. Relative water content decreased with increasing in salinity level as difference between the lowest $(67.60 \% ; 30 \mathrm{mM})$ and the highest (90.16\%; plants sprayed with $25 \mathrm{mg} \cdot \mathrm{L}^{-1} \mathrm{SiO}_{2}$-NPs). Presumably, the presence of silicon residues has been found in epidermal cell walls, which are related to water loss of cuticle and extreme transpiration (Mateos-Naranjo et al., 2013). The amount of leaf chlorophyll significantly decreased when gerbera plants were exposed to salt stress. Under several salinity conditions, the severe salinity $(30 \mathrm{mM} \mathrm{NaCl})$ cause a high reduction of $40 \%$ in the leaf chlorophyll of gerbera plants against controls
(Table 4). Reduction in concentration of chlorophyll is likely because of the accumulation of different salt ions and prevention of chlorophyll biosynthesis or membrane deterioration (Ashraf and Bhatti, 2000). It also may be related to the activation of chlorophyllase enzyme and consequently degraded the chlorophyll (Santos, 2004).

\section{Biochemical contents and antioxidant enzyme activities of gerbera plants in response to $\mathrm{SiO}_{2}-$ NPs treatment with and without salinity}

The amount of proline in leaves gerbera plant under salinity increased by $32,384,1,046$ and $1231 \%$ under 5, 10, 20 and $30 \mathrm{mM} \mathrm{NaCl}$ treatments, respectively; but incorporation of $\mathrm{SiO}_{2}-\mathrm{NPs}$ sprays on plants limited the proline accumulation. Results were in agreement with Moussa (2006) and Lee et al. (2010) in maize and soybean, respectively. Sever salinity $(30 \mathrm{mM})$ cause to decrease 
in protein by $54 \%$ compared to controls (Table 4 ). It has been demonstrated that proline is a possible source of carbon and nitrogen for rapid recovery of plant after exposure to salt stress. In addition, it is a membrane and some macromolecules stabiliser as well as scavenger for reactive oxygen species. Some articles have concluded that $\mathrm{SiO}_{2}-\mathrm{NPs}$ have harmful effects, but it has also been concluded that the toxic effect of $\mathrm{SiO}_{2}-\mathrm{NP}$ could be due of an alteration in the $\mathrm{pH}$ of the growing media after $\mathrm{SiO}_{2}-\mathrm{NP}$ addition (Slomberg and Schoenfisch, 2012). In any case, the amount of proline in the nutrient solution increased from 2.74 to $32.41 \mathrm{mmol} \cdot \mathrm{g}^{-1} \mathrm{FW}$ as the salinity level increased, but adding $\mathrm{SiO}_{2}-\mathrm{NPs}$ to the nutrient solution prevented proline accumulation. Similar results were obtained in strawberry (Avestan et al., 2019). Since lipid peroxidation was significantly lower in gerbera plants treated with Si under salinity than in the same treated plants without $\mathrm{Si}$ application, $\mathrm{SiO}_{2}$-NPs have beneficial effect in preventing lipid peroxidation induced by salinity. This effect of $\mathrm{Si}$ was more considerable at 20 and $30 \mathrm{mM} \mathrm{NaCl}$. Salinity caused a $54 \%$ decrease in protein compared to controls (Table 4).

Antioxidant enzyme activities play an important role as reactive oxygen species scavengers, which can improve the ability of plant tolerance under stress conditions. Following the increase in salinity, the changes in activities of SOD, GPX, APX, $\mathrm{H}_{2} \mathrm{O}_{2}$ and MDA had similar tendency as their activities were simulated by salt stress (Figures 3 and 4). However, the increase was higher in controls than in plants treated with $\mathrm{SiO}_{2}$ NPs. Under salt stress, the activity of APX and GPX was significantly increased after the application of $\mathrm{SiO}_{2}$ NPs (Figure 3A and B) but not in SOD, although the difference between treated and untreated plants was not significant (Figure 3C). According to Figure 3C, spray of $50 \mathrm{mg} \cdot \mathrm{L}^{-1} \mathrm{SiO}_{2}$ nanoparticles could suppress the increase of SOD activity in plants under $10 \mathrm{mM}$ salinity. This probably indicates that plants are not affected by these stress conditions. The increase in the activity of antioxidant enzymes by silicone spray under salinity is the protective way for inhibition of oxidative stress in plants which is the first defense mechanism of salinity reduction induced upon Silicone application (Soundararajan et al., 2014). Improving in growth characteristics and nutrition uptake by supplementation of $\mathrm{SiO}_{2}$-NPs might be result of a reduction in oxidative stress as by activation of APX and GPX although the activity of SOD was unchanged. Results were in agreement with Abdul Qados (2015) in faba bean sprayed with nano silicon under salinity stress.

The decrease in the amount of malondialdehyde and electrolyte leakage followed by $\mathrm{SiO}_{2}$-NPs application might be due to activation of antioxidant enzymes and consequently protect the plants from oxidative stress, increase in the stability of membrane and protect plant from harmful effects of reactive oxygen species (Rubinowska et al., 2014). In addition, it seems that increase in the $\mathrm{Ca}^{2+}$ uptake can cause to protect of plant from oxidative stress.

\section{Nutrient uptake of gerbera plants in response to $\mathrm{SiO}_{2}$-NPs treatment with and without salinity}

Gerbera plants treated with $\mathrm{SiO}_{2}-\mathrm{NPs}$ had higher $\mathrm{Ca}^{2+}$ and $\mathrm{K}^{+}$content in leaves especially at $25 \mathrm{mg} \cdot \mathrm{L}^{-1}$ level of $\mathrm{SiO}_{2}$ nano particles, in comparison with other treatments, regardless of the salinity level (Table 5). Supplementation of $\mathrm{SiO}_{2}$-NPs also led to the decrease in $\mathrm{Na}^{+}$content as compared with controls and treatments with salinity lower than $30 \mathrm{mM}$ both sprayed with $25 \mathrm{mg} \cdot \mathrm{L}^{-1} \mathrm{SiO}_{2}-\mathrm{NP}$ were in the range of 0.64 up to $2.97 \mathrm{~g} \cdot \mathrm{g}^{-1} \mathrm{FW}$. The highest $\mathrm{Na}^{+}$content $\left(3.17 \mathrm{~g} \cdot \mathrm{g}^{-1}\right.$ FW) was related to $30 \mathrm{mM}$ salinity, whereas the least was for control plants treated with $25 \mathrm{mg} \cdot \mathrm{L}^{-1} \mathrm{SiO}_{2}-\mathrm{NPs}$ $\left(0.64 \mathrm{~g} \cdot \mathrm{g}^{-1} \mathrm{FW}\right)$. Leaf $\mathrm{Na}^{+}$content increased from 0.89 to $3.17 \mathrm{~g} \cdot \mathrm{g}^{-1} \mathrm{FW}$ and in the opposite trend $\mathrm{K}^{+}$content decreased from 1.77 to $0.85 \mathrm{~g} \cdot \mathrm{g}^{-1} \mathrm{FW}$ following the increase in salinity levels up to $30 \mathrm{mM}$. Salinity not only can disrupt $\mathrm{K}^{+}$uptake but also might disrupt the cell membrane, thus affecting its power of ion selection (Perez-Alfocea et al., 1996). Niu et al. (2012) showed that zinnia was sensitive to salinity as plant height became shorter and more compact as well as increase in electrolyte conductivity of irrigation water. Also, dry weight of shoot in EC values of $4.2 \mathrm{dS} \cdot \mathrm{m}^{-1}$ reduced by $50 \%$ and $\mathrm{Na}^{+}$and $\mathrm{Cl}^{-}$accumulated excessively, whereas $\mathrm{Ca}^{2+}, \mathrm{Mg}^{2+}$ and $\mathrm{K}^{+}$did not change substantially. One of the effects of salinity is the elimination of $\mathrm{K}^{+}$by plant roots and consequently imbalance in plant physiology since $\mathrm{K}^{+}$is necessary to the synthesis of protein. Losses of $\mathrm{K}^{+}$cause to reduce of plant growth (Chen et al., 2007). As shown in Table 4, $\mathrm{SiO}_{2}$-NPs can prevent protein degradation at high $\mathrm{NaCl}$ concentrations by up to 17 and $45 \%$ at 25 and $30 \mathrm{mM} \mathrm{NaCl}$, respectively. The incorporation of $\mathrm{SiO}_{2}$-NPs improved the absorption of $\mathrm{K}^{+}$ and likely prevent protein degradation. The application of $\mathrm{SiO}_{2}$-NPs improved leaf potassium level under salt stress. It also significantly reduced the level of leaf $\mathrm{Na}^{+}$ and caused to improve in the $\mathrm{K}^{+} / \mathrm{Na}^{+}$and $\mathrm{Ca}^{2+} / \mathrm{Na}^{+}$ratios in leaves. These results are in agreement with Kafi and Rahimi (2011) on purslane and $\mathrm{Xu}$ and Liu (2015) an aloe. However, the highest $\mathrm{Ca}^{2+} / \mathrm{Na}^{+}$and $\mathrm{K}^{+} / \mathrm{Na}^{+}$ratios were related to the control plants sprayed with 25 and $50 \mathrm{mg} \cdot \mathrm{L}^{-1} \mathrm{SiO}_{2}$-NPs and the lower values are related to 20 and $30 \mathrm{mM}$ level of salinity regardless of the $\mathrm{SiO}_{2}-$ NPs treatment (Table 5).

This finding means that the improving effects of $\mathrm{SiO}_{2}$-NPs were so evident in $10 \mathrm{mM}$ salinity. On the other hand, salinity caused to decrease in $\mathrm{Ca}^{2+}$ content by $61 \%$. Therefore, under salinity stress, the calcium requirement of plant is higher than those in non-saline conditions. Also, salt stress effect on leaf $\mathrm{Ca}^{2+} / \mathrm{K}^{+}$ratio negatively, as decreased by $21 \%$ under $30 \mathrm{mM}$ salinity, whereas in the same situation application of 25 and $50 \mathrm{mg} \cdot \mathrm{L}^{-1} \mathrm{SiO}_{2}-\mathrm{NPs}$, it was reduced only by 7 and $10 \%$, respectively. 

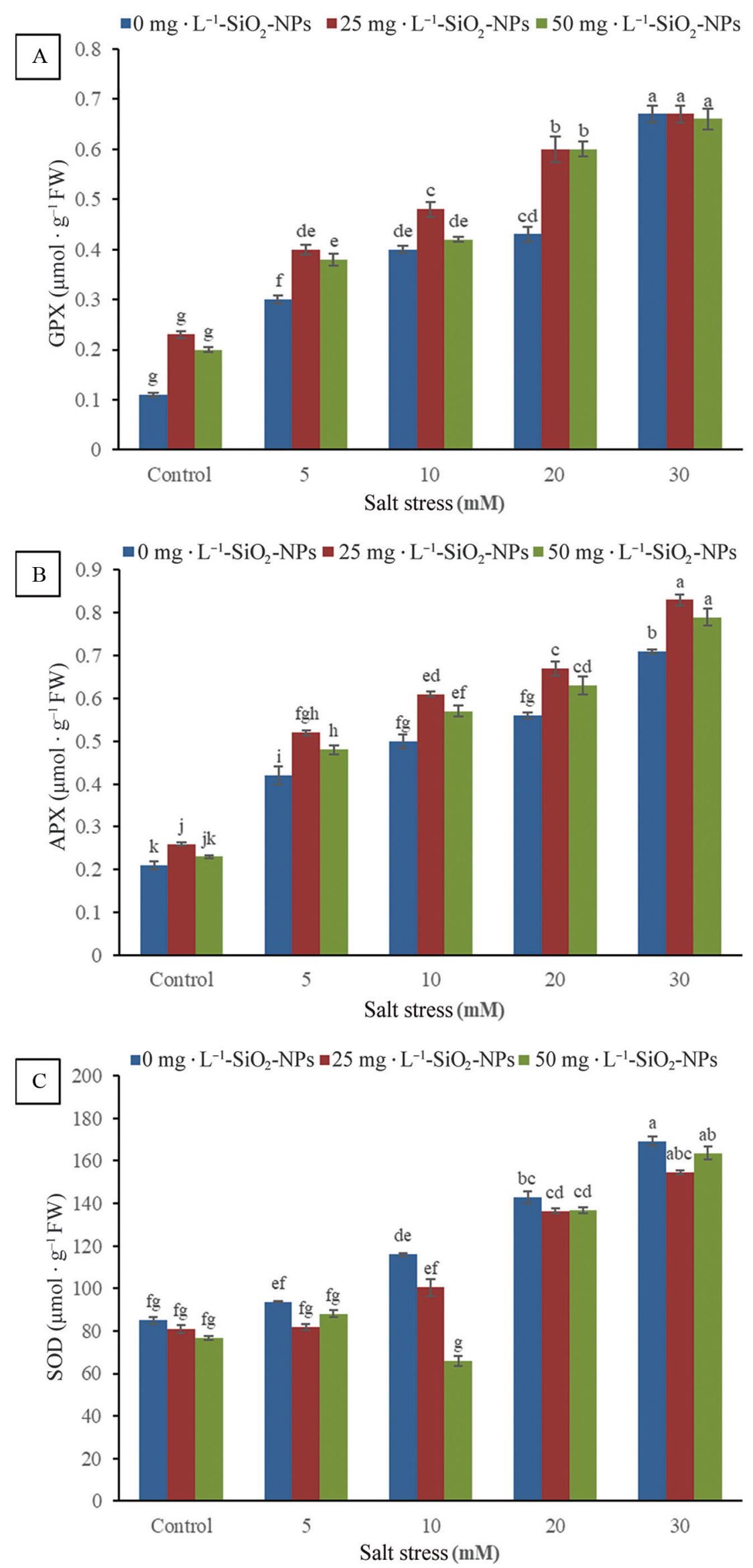

Figure 3. Effect of $\mathrm{SiO}_{2}$-NPs and salt stress on GPX (A), APX (B) and SOD (C) activity in gerbera cv. 'Teera Kalina' leaves. APX, ascorbate peroxidase; GPX, guaiacol peroxidase; SOD, superoxide dismutase. 

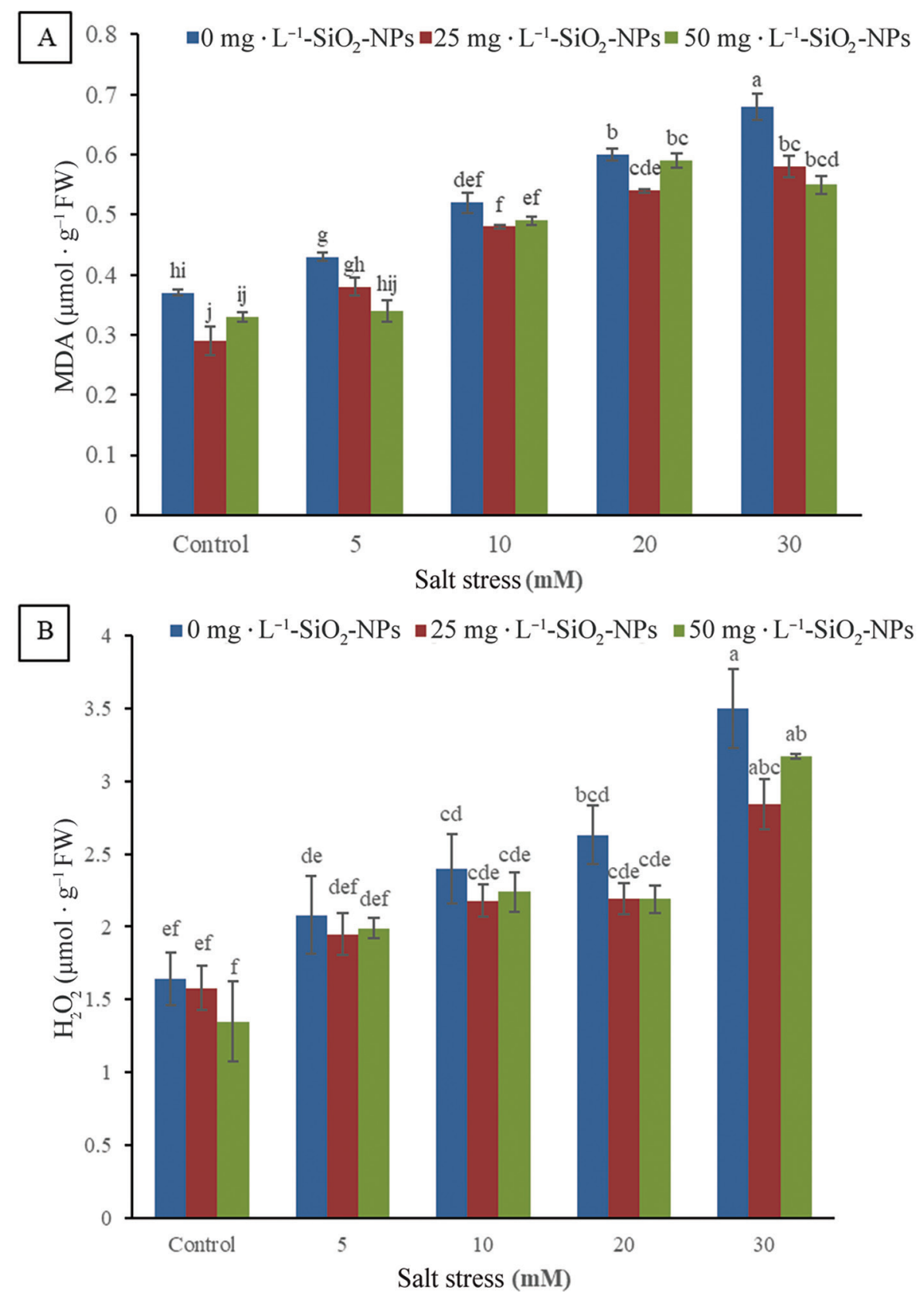

Figure 4. Effect of $\mathrm{SiO}_{2}-\mathrm{NPs}$ and salt stress on MDA (A) and $\mathrm{H}_{2} \mathrm{O}_{2}$ (B) in gerbera cv. 'Teera Kalina' leaves. $\mathrm{H}_{2} \mathrm{O}_{2}$, hydrogen peroxide; MDA, malondialdehyde.

Increased resistance to salinity levels in gerbera plant under the application of $\mathrm{SiO}_{2}$-NPs most likely was because of the reduction in $\mathrm{Na}^{+}$uptake and detoxification of plant from $\mathrm{Na}^{+}$by increasing in $\mathrm{Na}^{+}$binding on cell wall (Kafi and Rahimi, 2011). Because of the same mechanisms of both $\mathrm{Na}^{+}$and $\mathrm{K}^{+}$uptake (Niu et al., 1995), $\mathrm{SiO}_{2}$-NPs can increase $\mathrm{K}^{+}$uptake by suppressing $\mathrm{Na}^{+}$uptake. It seems that silicon acts as a competitive inhibitor for $\mathrm{Na}^{+}$therefore, using $25 \mathrm{mg} \cdot \mathrm{L}^{-1} \mathrm{SiO}_{2}-\mathrm{NPs}$ led to the decrease in $\mathrm{Na}^{+}$content by $28 \%$ (control), $2 \%$ $(5 \mathrm{mM}), 14 \%(10 \mathrm{mM}), 15 \%(20 \mathrm{mM})$ and $6 \%(30 \mathrm{mM})$ of salinity levels. The auxiliary effect of $25 \mathrm{mg} \cdot \mathrm{L}^{-1}$ $\mathrm{SiO}_{2}-\mathrm{NPs}$ in $\mathrm{K}^{+}$uptake in control was $31 \%$, whereas in $30 \mathrm{mM}$ salinity it was $27 \%$. This indicates the higher effect of $\mathrm{SiO}_{2}$-NPs under stress conditions and ion homeostasis of gerbera plants was kept well. The improvement of salt stress by using $\mathrm{SiO}_{2}$-NPs treatments was accompanied with improved membrane stability, enhancing the activity of enzymes and nutrition uptake. It has been known that $\mathrm{Si}$ can be beneficial for some crop species. Therefore, it has been used increasingly as a supplement in hydroponic nutrient solutions (Savvas et al., 2002). Under salinity, it has been demonstrated that the beneficial effects of silicone are because of the decreased level of $\mathrm{Na}^{+}$(Matoh et al., 1986; Bradbury and Ahmad, 1990; Liang et al., 2003), increased level of $\mathrm{K}^{+}$ (Liang et al., 1996) and enhaced photosynthesis rate in some plants (Liang, 1998; Al-Aghabary et al., 2004). 
Table 5. Effect of $\mathrm{SiO}_{2}$-NPs and salt stress on nutrient uptake of gerbera cv. 'Teera Kalina'.

\begin{tabular}{|c|c|c|c|c|}
\hline \multicolumn{2}{|l|}{ Treatments } & \multirow{2}{*}{$\begin{array}{c}\mathrm{Ca}^{2+} \\
\left(\mathrm{g} \cdot 100 \mathrm{~g}^{-1} \mathrm{FW}\right)\end{array}$} & \multirow{2}{*}{$\begin{array}{c}\mathrm{K}^{+} \\
\left(\mathrm{g} \cdot 100 \mathrm{~g}^{-1} \mathrm{FW}\right)\end{array}$} & \multirow{2}{*}{$\begin{array}{c}\mathrm{Na}^{+} \\
\left(\mathrm{g} \cdot 100 \mathrm{~g}^{-1} \mathrm{FW}\right)\end{array}$} \\
\hline Salinity $(\mathrm{mM})$ & $\mathrm{SiO}_{2}-\mathrm{NPs}\left(\mathrm{mg} \cdot \mathrm{L}^{-1}\right)$ & & & \\
\hline \multirow[t]{3}{*}{ Control } & 0 & $2.38 \pm 0.07 \mathrm{~cd}$ & $1.77 \pm 0.04 \mathrm{bc}$ & $0.89 \pm 0.02 \mathrm{~h}$ \\
\hline & 25 & $2.69 \pm 0.01 \mathrm{~b}$ & $2.33 \pm 0.06 \mathrm{a}$ & $0.64 \pm 0.04 \mathrm{i}$ \\
\hline & 50 & $2.94 \pm 0.02 \mathrm{a}$ & $1.86 \pm 0.01 \mathrm{~b}$ & $0.70 \pm 0.02 \mathrm{i}$ \\
\hline \multirow[t]{3}{*}{5} & 0 & $2.22 \pm 0.04 \mathrm{de}$ & $1.69 \pm 0.02 \mathrm{c}$ & $1.72 \pm 0.03 \mathrm{f}$ \\
\hline & 25 & $2.42 \pm 0.05 \mathrm{c}$ & $1.71 \pm 0.02 \mathrm{c}$ & $1.24 \pm 0.01 \mathrm{~g}$ \\
\hline & 50 & $2.45 \pm 0.05 \mathrm{c}$ & $1.86 \pm 0.04 \mathrm{~b}$ & $1.29 \pm 0.01 \mathrm{~g}$ \\
\hline \multirow[t]{3}{*}{10} & 0 & $2.11 \pm 0.04 \mathrm{e}$ & $1.23 \pm 0.04 \mathrm{e}$ & $2.28 \pm 0.01 \mathrm{~d}$ \\
\hline & 25 & $2.20 \pm 0.04 \mathrm{de}$ & $1.46 \pm 0.03 \mathrm{~d}$ & $1.96 \pm 0.07 \mathrm{e}$ \\
\hline & 50 & $2.15 \pm 0.08 \mathrm{e}$ & $1.50 \pm 0.05 \mathrm{~d}$ & $2.49 \pm 0.03 \mathrm{c}$ \\
\hline \multirow[t]{3}{*}{20} & 0 & $1.55 \pm 0.04 \mathrm{f}$ & $1.01 \pm 0.04 \mathrm{fg}$ & $2.63 \pm 0.06 \mathrm{c}$ \\
\hline & 25 & $1.59 \pm 0.02 \mathrm{f}$ & $1.28 \pm 0.02 \mathrm{e}$ & $2.21 \pm 0.03 \mathrm{~d}$ \\
\hline & 50 & $1.72 \pm 0.03 \mathrm{f}$ & $1.02 \pm 0.03 \mathrm{fg}$ & $2.23 \pm 0.04 \mathrm{~d}$ \\
\hline \multirow[t]{3}{*}{30} & 0 & $0.91 \pm 0.08 \mathrm{~h}$ & $0.85 \pm 0.01 \mathrm{~h}$ & $3.17 \pm 0.03 \mathrm{a}$ \\
\hline & 25 & $1.14 \pm 0.06 \mathrm{~g}$ & $1.08 \pm 0.05 \mathrm{f}$ & $2.97 \pm 0.05 \mathrm{~b}$ \\
\hline & 50 & $1.31 \pm 0.02 \mathrm{~g}$ & $0.93 \pm 0.03 \mathrm{gh}$ & $2.50 \pm 0.08 \mathrm{c}$ \\
\hline \multicolumn{2}{|l|}{ Treatments } & $\mathrm{Ca}^{2+} / \mathrm{K}^{+}$ & $\mathrm{Ca}^{2+} / \mathrm{Na}^{+}$ & $\mathrm{K}^{+} / \mathrm{Na}^{+}$ \\
\hline Salinity (mM) & $\mathrm{SiO}_{2}-\mathrm{NPs}\left(\mathrm{mg} \cdot \mathrm{L}^{-1}\right)$ & & & \\
\hline \multirow[t]{3}{*}{ Control } & 0 & $1.35 \pm 0.05 \mathrm{cdef}$ & $2.68 \pm 0.07 \mathrm{~b}$ & $1.99 \pm 0.11 \mathrm{c}$ \\
\hline & 25 & $1.16 \pm 0.04 \mathrm{fg}$ & $4.22 \pm 0.09 \mathrm{a}$ & $3.66 \pm 0.32 \mathrm{a}$ \\
\hline & 50 & $1.57 \pm 0.01 \mathrm{ab}$ & $4.17 \pm 0.08 \mathrm{a}$ & $2.65 \pm 0.09 \mathrm{~b}$ \\
\hline \multirow[t]{3}{*}{5} & 0 & $1.31 \pm 0.04 \mathrm{def}$ & $1.29 \pm 0.05 \mathrm{de}$ & $0.98 \pm 0.02 \mathrm{e}$ \\
\hline & 25 & $1.42 \pm 0.04$ bcde & $1.94 \pm 0.07 \mathrm{c}$ & $1.37 \pm 0.04 \mathrm{~d}$ \\
\hline & 50 & $1.31 \pm 0.01 \mathrm{def}$ & $1.89 \pm 0.06 \mathrm{c}$ & $1.44 \pm 0.04 \mathrm{~d}$ \\
\hline \multirow[t]{3}{*}{10} & 0 & $1.72 \pm 0.05 \mathrm{a}$ & $0.92 \pm 0.03$ ef & $0.53 \pm 0.02 \mathrm{fg}$ \\
\hline & 25 & $1.51 \pm 0.02 \mathrm{abcd}$ & $1.12 \pm 0.04 \mathrm{de}$ & $0.75 \pm 0.04$ ef \\
\hline & 50 & $1.45 \pm 0.09$ bcde & $0.86 \pm 0.03 \mathrm{efg}$ & $0.60 \pm 0.02 \mathrm{fg}$ \\
\hline \multirow[t]{3}{*}{20} & 0 & $1.54 \pm 0.02 \mathrm{abc}$ & $0.59 \pm 0.01 \mathrm{fghi}$ & $0.38 \pm 0.02 \mathrm{fg}$ \\
\hline & 25 & $1.24 \pm 0.03 \mathrm{efg}$ & $0.72 \pm 0.02 \mathrm{fgh}$ & $0.58 \pm 0.02 \mathrm{fg}$ \\
\hline & 50 & $1.69 \pm 0.06 \mathrm{a}$ & $0.77 \pm 0.02 \mathrm{efg}$ & $0.45 \pm 0.01 \mathrm{fg}$ \\
\hline \multirow[t]{3}{*}{30} & 0 & $1.06 \pm 0.09 \mathrm{~g}$ & $0.28 \pm 0.03 \mathrm{i}$ & $0.26 \pm 0.01 \mathrm{~g}$ \\
\hline & 25 & $1.07 \pm 0.09 \mathrm{~g}$ & $0.38 \pm 0.02 \mathrm{hi}$ & $0.37 \pm 0.03 \mathrm{~g}$ \\
\hline & 50 & $1.41 \pm 0.04$ bcde & $0.52 \pm 0.03$ ghi & $0.37 \pm 0.02 \mathrm{~g}$ \\
\hline
\end{tabular}

Values represent means \pm standard errors of three independent replications $(n=3)$.

Different letters within the same column indicate significant differences at $p<0.05$ among the treatments, according to Duncan's multiple range test.

$\mathrm{Ca}^{2+}$, calcium; $\mathrm{K}^{+}$, potassium; $\mathrm{Na}^{+}$, sodium.

\section{Pearson correlation analysis}

Pearson correlation analysis showed that $\mathrm{Na}^{+}$ concentration was correlated with EL and MSI, positively. Similarly, a positive correlation was detected between $\mathrm{Na}^{+}$and antioxidative enzyme activities (SOD, APX and GPX), oxidative markers (MDA and $\mathrm{H}_{2} \mathrm{O}_{2}$ ) and proline. In contrast, $\mathrm{Na}^{+}$concentration displayed a negative correlation with morphological parameters (leaf and flower number, plant FW and DW, stem length and diameter, flower diameter and LA) (Figure 5).

\section{CONCLUSIONS}

Salinity may have an adverse effect on plant's growth, development and even survival by causing osmotic toxicity and nutritional imbalance. Although the results indicated that gerbera can likely tolerate salinity levels up to $10 \mathrm{mM}$, and in higher salinity levels, it will be negatively affected. The findings of this experiment demonstrated that $\mathrm{Si}$ nano particles have positive effects on gerbera plants that are salt stressed. When $25 \mathrm{mg} \cdot \mathrm{L}^{-1}$ $\mathrm{SiO}_{2}$-NPs were applied to salinity stressed plants, the content of $\mathrm{Na}^{+}$was reduced, and the plants had better conditions; this may be the primary mechanism involved in the amelioration of salt effects. The beneficial effects of $\mathrm{SiO}_{2}-\mathrm{NP}$ on photoassimilation efficiency and plant performance at different levels of salinity have been related to 1) the prevention of photoinhibition in photosynthetic apparatus and consequently increase in photosynthesis, 2) accumulation of photoassimilates to balance cell osmotic status, 3) an increase in antioxidative enzyme activities to scavenge reactive oxygen species and 4) changes in nutrient content to increase fruit quality. Therefore, it seems reasonable 


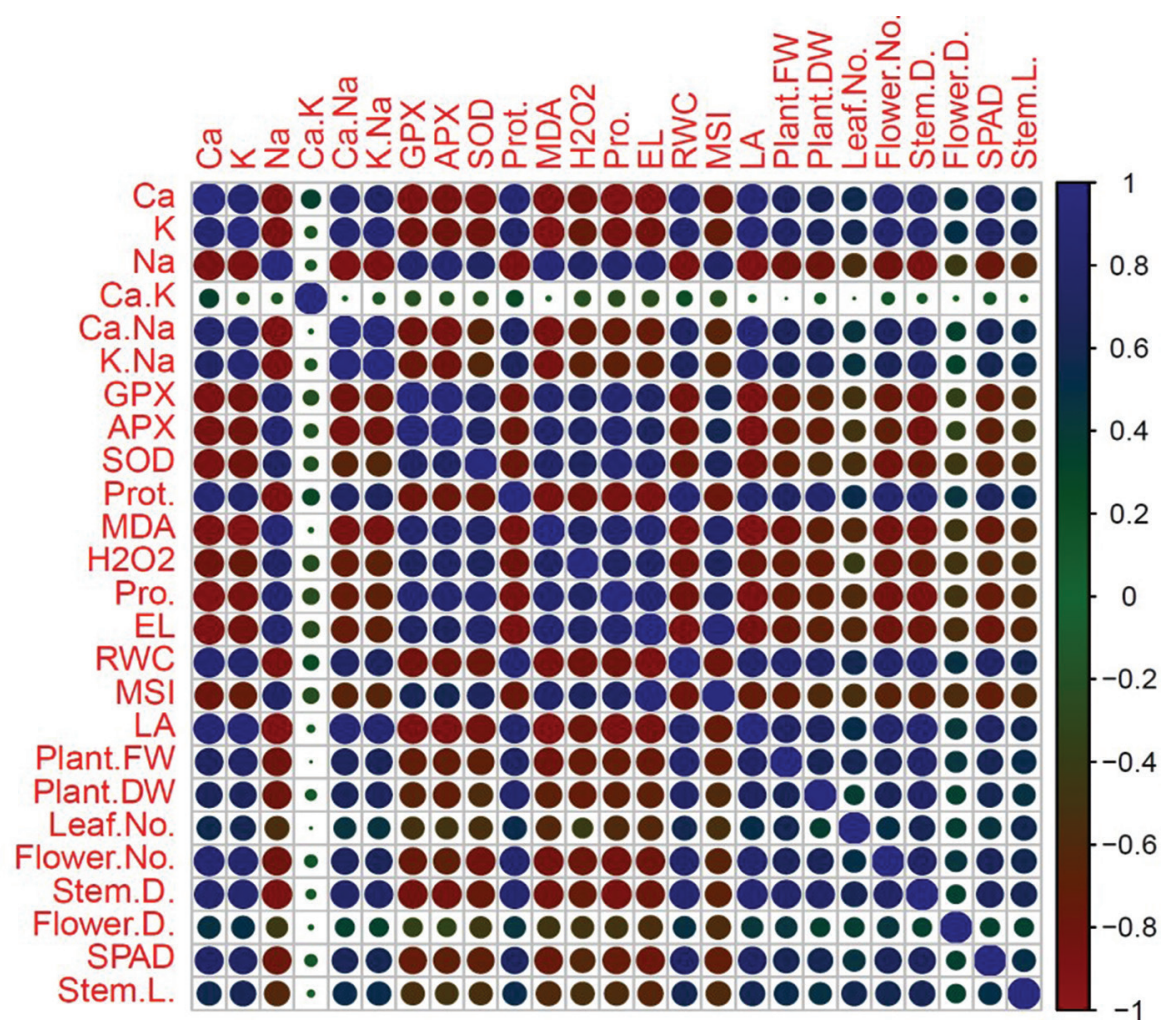

Figure 5. Pearson correlation analysis of $\mathrm{SiO}_{2}-\mathrm{NPs}$ treatment and variable trait relationship in gerbera plants grown under non-saline and different saline conditions. Heatmap of Pearson correlation coefficient $(r)$ values of variable traits, where the coloured scale indicates the positive (blue) or negative (red) correlation and the ' $r$ ' coefficient values $(r=-1.0$ to 1.0$)$. The tested variables included are APX, ascorbate peroxidase; $\mathrm{Ca}^{2+}$, calcium; EL, electrolyte leakage; Flower D., flower diameter; Flower No., flower number; GPX, guaiacol peroxidase; $\mathrm{H}_{2} \mathrm{O}_{2}$ hydrogen peroxidase; LA, leaf area; Leaf No., leaf number; MDA, malondialdehyde; MSI, membrane stability index; Plant DW, plant dry weight; Plant FW, plant fresh weight; $\mathrm{K}^{+}$, potassium; Pro, proline; Pro, protein; RWC, relative water content; $\mathrm{Na}^{+}$, sodium; Stem D., stem diameter; Stem L., stem length; SOD, superoxide dismutase.

to conclude that in exposure to salinity up to $30 \mathrm{mM}$ reduces flower yield in hydroponic gerbera plants due to osmotic rather than ion-specific effects.

\section{ACKNOWLEDGEMENTS}

The authors are grateful to the University of Maragheh for providing financial support.

\section{FUNDING}

The present study was supported by the MS.c project entitled 'Effects of nanosilicon foliar spray on growth and quality of gerbera (Gerbera jamesonii $\mathrm{H}$. Bol) under salinity', which was funded by the Vice Chancellor for Research, University of Maragheh.

\section{AUTHOR CONTRIBUTIONS}

H.S.H. and S.M.Z perceived the idea. M.A. conducted the field experiments. H.S.H., S.M.Z., N.H. and F.R. collected and analysed the data. H.S.H wrote first draft of manuscript. H.S.H., S.M.Z., N.H., M. H. and T. A. reviewed and prepared final draft of manuscript.

\section{CONFLICT OF INTEREST}

Authors declare no conflict of interest.

\section{REFERENCES}

Abdul Qados, A. M. S. (2015). Mechanism of nanosilicon-mediated alleviation of salinity stress in faba bean (Vicia faba L.) plants. American Journal of Experimental Agriculture, 7(2), 78-95.

Akat, Ö., Tüzel, I. H., and Özzambak, M. E. (2009). The effects of different salinity levels and leaching fractions on yield and water consumption of gerbera plants. Acta Horticulturae, 807, 233-238.

Al-Aghabary, K., Zhu, Z. J., And Shi, Q. H. (2004). Influence of silicon supply on chlorophyll content, chlorophyll fluorescence and antioxidative enzyme activities in tomato plants under salt stress. Journal of Plant Nutrition, 27, 2101-2115.

Ali, B., Hayat, S., Hasan, S. A., Hayat, Q., Yadav, S., Fariduddin, Q., And Ahmad, A. (2008). A role for brassinosetroids in the amelioration of aluminium stress through antioxidant system in mungbean 
(Vigna radita L. Wilczek). Environmental and Experimental Botany, 62, 153-159.

Ashraf, M. Y., And Bhatti, A. S. (2000). Effect of salinity on growth and chlorophyll content of Rice. Pakistan Journal of Scientific and Industrial Research, 43(2), 130-131.

Avestan, S., Ghasemnezhad, M., Esfahani, M., And Byrt, C. S. (2019). Application of nano-silicon dioxide improves salt stress tolerance in strawberry plants. Agronomy, 9(5), 246, doi: 10.3390/ agronomy 9050246.

Bates, L. S., Waldren, R. P., and Teare, I. D. (1973). Rapid determination of free proline for water stress studies. Plant Soil, 39(1), 205-207.

Bayat, H., Alirezaie, M., Neamati, M., and Abdollahi SAADABAD, A. (2013). Effect of silicon on growth and ornamental traits of salt-stressed calendula (Calendula officinalis L.). Propagation of Ornamental Plants, 3(4), 2251-6441.

Beauchamp, C., and Fridovich, I. (1971). Superoxide dismutase: Improved assays and an assay applicable to acrylamide gels. Analytical Biochemistry, 44, 276-287.

Bradbury, M., And Ahmad, R. (1990). The effect of silicon on the growth of Prosopis juliflora growing in saline soil. Plant and Soil, 125, 71-74.

BRADFORD, M. M. (1976). A rapid and sensitive method for the quantitation of microgram quantities of protein utilizing the principle of protein-dye binding. Analytical Biochemistry, 72(1-2), 248-254.

Brown, P. H., Bellaloui, N., Wimmer, M. A., Bassil, E. S., Ruis, J., Hu, H., Pfeffer, H., Dannel, F., And Römheld, V. (2002). Boron in plant biology. Plant and Soil, 4, 211-229.

Carmassi, G., Bacci, L., Bronzini, M., Incrocci, L., Maggini, R., Bellocchi, G., Massa, D., and Pardossi, A. (2013). Modelling transpiration of greenhouse gerbera (Gerbera jamesonii H. Bolus) grown in substrate with saline water in a Mediterranean climate. Scientia Horticulturae, 156, 9-18.

Carvalho-Zanão, M. P., Zañ̃o Júnior, L. A., Barbosa, J. G., Grossi, J. A. S., And Ávila, V. T. (2012). Yield and shelf life of chrysanthemum in response to the silicon application. Horticultura Brasileira, 30, 403-408.

Chen, Z., Cuin, T. A., Zhou, M., Twomey, A., Naidu, B. P., and Shabala, S. (2007). Compatible solute accumulation and stress-mitigating effects in barley genotypes contrasting in their salt tolerance. Journal of Experimental Botany, 58, 4245-4255.

Conceição, S. S., Oliveira Neto, C. F. D., Marques, E. C., Barbosa, A. V. C., Galvão, J. R., Oliveira, T. B. D., And Gomes-Filho, E. (2019). Silicon modulates the activity of antioxidant enzymes and nitrogen compounds in sunflower plants under salt stress. Archives of Agronomy and Soil Science, 65(9), 1237-1247.
Epstein, E. (1994). The anomaly of silicon in plant biology. Proceedings of the National Academy of Sciences of the United States of America, 91(1), 11-17.

Ganege Don, K. K., Xia, Y. P., Zhu, Z., Le, C., And Wijeratne, A. W. (2010). Some deleterious effects of long-term salt stress on growth, nutrition, and physiology of gerbera (Gerbera jamesonii L.) and potential indicators of its salt tolerance. Journal of Plant Nutrition, 33, 2010-2027.

Gómez Bellot, M. J., Carmassi, G., Bartalucci, M., Sánchez-Blanco, M. J., And Pardossi, A. (2018). Growth, evapotranspiration and mineral content of gerbera under combined salinity and excess boron. Journal of Horticultural Research, 26(2), 61-69.

Hajizadeh, H. S., Heidari, B., Bertoldo, G., Della Lucia, M. C., Magro, F., Broccanello, C., and Concheri, G. (2019). Expression profiling of candidate genes in sugar beet leaves treated with leonardite-based biostimulant. High-Throughput, 8(4), 18. doi: 10.3390/ht8040018.

Hossain, Z., Mustafa, G., and Komatsu, S. (2015). Plant responses to nanoparticle stress. International Journal of Molecular Sciences, 16(11), 26644-26653.

Hwang, S. J., Jeong, B. R., And Park, H. M. (2005). Effects of potassium silicate on the growth of miniature rose 'Pinocchio' grown on rockwool and its cut flower quality. Journal of the Japanese Society for Horticultural Science, 74, 242-247.

Jamali, B., And Rahemi, M. (2011). Carnation flowers senescence as influenced by nickel, cobalt and silicon. Journal of Biodiversity and Environmental Sciences, 5(15), 147-152.

JanA, S., AND JEONG, B. R. (2014). Silicon: the most under-appreciated element in horticultural crops. Trends in Horticultural Research, 4, 1-19.

Kafi, M., And Rahimi, Z. (2011). Effect of salinity and silicon on root characteristics, growth, water status, proline content and ion accumulation of purslane (Portulaca oleracea L.). Journal of Soil Science and Plant Nutrition, 57(2), 341-347.

Kalteh, M., Alipour, Z. T., Ashraf, S., Aliabadi, M. M., And Nosratabadi, A. F. (2014). Effect of silica nanoparticles on basil (Ocimum basilicum) under salinity stress. Journal of Chemical Health Risks, 4(3), 49-55.

Kamenidou, S, Cavins, T. J., And Marek, S. (2010). Silicon supplements affect floricultural quality traits and elemental nutrient concentrations of greenhouse produced gerbera. Scientai Horticulturae, 119, $297-$ 301.

Kulkarni, K. V., Thawal, D. W., Kharbade, S. B., Shaikh, A. A., And Jagtap, K. B. (2017). Economic of potted gerbera with different growth media under protected cultivation in pune. International Journal of Agricultural Economics, 7(1), 1-6. 
LAANE, H. M. (2018). The effects of foliar sprays with different silicon compounds. Plants, 7(2), 45. doi: $10.3390 /$ plants7020045.

Lauchli, A., And Grattan, S. R. (2007). Plant growth and development under salinity stress. In M. A. Jenks, P. M. Hasegawa, and S. M. Jain (Eds), Advances in molecular breeding towards salinity and drought tolerance (pp. 1-32). Netherlands: Springer.

Lee, S. K., Sohn, E. Y., Hamayun, M., Yoon, J. Y., AND LEE, I. J. (2010). Effect of silicon on growth and salinity stress of soybean plant grown under hydroponic system. Agroforestry Systems, 80, 333-340.

LiAng, Y. C. (1998). Effects of silicone on leaf ultrastructure, chlorophyll content and photosynthetic activity in barley under salt stress. Pedosphere, 8, 289-296.

Liang, Y. C., Shen, Q. R., Shen, Z. G., AND Ma, T. S. (1996). Effects of silicon on salinity tolerance of two barley cultivars. Journal of Plant Nutrition, 19, 173-83.

Liang, Y. C., Chen, Q., Liu, Q., Zhang, W. H., And Ding, R. X. (2003). Exogenous silicon increases antioxidant enzyme activity and reduces lipid peroxidation in roots of salt-stressed barley (Hordeum vulgare L.). Journal of Plant Physiology, 160, 1157-1164.

Liu, Y. H., Offler, C. E., And Ruan, Y. L. (2014). A simple, rapid, and reliable protocol to localize hydrogen peroxide in large plant organs by DABmediated tissue printing. Frontiers of Plant Science, 5, 745. doi: 10.3389/fpls.2014.00745.

Lutts, S., Kinet, J. M., and Bouharmont, J. (1996). $\mathrm{NaCl}$-induced senescence in leaves of rice (Oryza sativa L.) cultivars differing in salinity resistance. Annals of Botany, 8, 389-398.

Luyckx, M., Hausman, J. F., Lutts, S., And Guerriero, G. (2017). Silicon and plants: current knowledge and technological perspectives. Frontiers of Plant Science, 8, 411. doi: 10.3389/fpls.2017.00411.

Malavolta, E., Vitti, G. C., and Oliveira, S. A. (1997). Avaliação do estado nutricional das plantas. Piracicaba, Brasil: Potafos.

MARSChNer, H. (2011). Marschner's mineral nutrition of higher plants. Academic Press.

Mateos-Naranjo, E., Andrades-Moreno, L., And Davy, A. J. (2013). Silicon alleviates deleterious effects of high salinity on the halophytic grass Spartina densiflora. Plant Physiology and Biochemistry, 63, 115-121.

Matoh, T., Kairusmee, P., and Takahashi, E. (1986). Salt-induced damage to rice plants and alleviation effect of silicate. The Journal of Soil Science and Plant Nutrition, 32, 295-304.

Moussa, H. R. (2006). Influence of exogenous application of silicon on physiological response of salt-stressed maize (Zea mays L.). International Journal of Agriculture and Biology, 8, 293-297.
Munns, R. (2002). Comparative physiology of salt and water stress. Plant, Cell and Environment, 25, 239 250 .

National Garden Bureau. Retrieved from www.ngb. org/index.cfm.

Niu, G., Wang, M., And Rodriguez, D. (2012). Response of zinnia plants to saline water irrigation. Hortscience, 47(6), 793-797.

Niu, X., Bressan, R. A., Hasegawa, P. M., and Pardo, J. M. (1995). Ion homeostasis in $\mathrm{NaCl}$ stress environments. Plant Physiology, 109(3), 735.

O'Farrell, N., Houlton, A., and Horrocks, B. R. (2006). Silicon nanoparticles: applications in cell biology and medicine. International Journal of Nanomedicine, 1(4), 451-472.

Paradiso, R., De Pascale, S., Aprea, F., and Barbieri, G. (2003). Effect of electrical conductivity levels of nutrient solution on growth, gas exchanges and yield of two gerbera cultivars in soilless system. Acta Horticulturae, 609, 165-171.

Perez-Alfocea, F., Balibrea, M. E., Santa Cruz, A., And Stan, M. T. (1996). Agronomical and physiological characterization of salinity tolerance in a commercial tomato hybrid. Plant and Soil, 180, 251-257.

Prasad, R., Bhattacharyya, A., and Nguyen Q. D. (2017). Nanotechnology in sustainable agriculture: recent developments, challenges, and perspectives. Frontiers in Microbiology, 8, 1014, doi: 10.3389/ fmicb.2017.01014.

Premachandra, G. S., Saneoka, H., Fujtta, K., and Ogata, S. (1990). Cell membrane stability and leaf water relations as affected by phosphorus nutrition under water stress in maize. Journal of Soil Science and Plant Nutrition, 36(4), 661-666.

Rastogi, A., Tripathi, D. K., Yadav, S., Chauhan, D. K., ŽIvČÁk, M., Ghorbanpour, M., El-Sheery, N. I., AND Brestic, M. (2019). Application of silicon nanoparticles in agriculture. 3 Biotech, 9, 90. doi: 10.1007/s13205-019-1626-7.

Ren, Z. H., Gao, J. P., Li, L. G., Cai, X. L., Huang, W., ChaO, D. Y., Zhu, M. Z., Wang, Z. Y., Luan, S., AND Lin, H. X. (2005). A rice quantitative trait locus for salt tolerance encodes a sodium transporter. Nature Genetics, 37, 1141-1146.

Rubinowska, K., Pogroszewska, E., Laskowska, H., Szot, P., Zdybel, A., Stasiak, D., and Kozak, D. (2014). The subsequent effect of silicon on physiological and biochemical parameters of Polygonatum multiflorum (L.) All. 'Variegatum' cut shoots. Acta Scientiarum Polonorum, Hortorum Cultus, 13(1), 167-178.

SAntos, C. V. (2004). Regulation of chlorophyll biosynthesis and degradation by salt stress in sunflower leaves. Scientia Horticulturae, 103(1), 93-99.

SARAVAnAVEl, R., Ranganathan, R., And AnANthaRAman, P. (2011). Effect of sodium chloride on phytosynthetic pigments and photosynthetic characteristics of 
Avicennia officinalis seedlings. Recent Research in Science and Technology, 3, 177-180.

Savvas, D., Gizas, G., Karras, G., Lydakis-Simantiris, N., Salahas, G., Papadimitriou, M., and Tsouka, N. (2007). Interactions between silicon and $\mathrm{NaCl}-$ salinity in a soilless culture of roses in greenhouse. European Journal of Horticultural Science, 72, 73-79.

Savvas, D., Manos, G., Kotsiras, A., and Souvaliotis, S. (2002). Effects of silicon and nutrient induced salinity on yield, flower quality, and nutrient uptake of gerbera grown in a closed hydroponic system. Journal of Applied Botany, 76, 153-158.

Shafiullah Prodhan, A. Z. M., Nazirul Islam Sarker, MD., Shahidul Islam, MD., And Arshad Ali, MD. (2017). Status and prospect of gerbera cultivation in Bangladesh. International Journal of Horticulture and Food Science, 1(1), 24-29.

Shani, U., And Dudley, L. M. (2001). Field studies of crop response to water and salt stress. Soil Science Society of America Journal, 65, 1522-1528.

Siddiqui, M. H., Al-Whaibi, M. H., Firoz, M., And Alkhaishany, M. Y. (2015). Role of nanoparticles in plants. In M. Siddiqui, M. Al-Whaibi, F. Mohammad (Eds), Nanotechnology and plant sciences (pp. 19-35). Springer.

Slomberg, D. L., And Schoenfisch, M. H. (2012). Silica nanoparticle phytotoxicity to Arabidopsis thaliana. Environmental Science and Environmental Technology, 46(18), 10247-10254.

Sonneveld, C., BaAs, R., Nijssen, H. M. C., And De Hoog, J. (2000). Effect of salinity substrate grown vegetables and ornamentals in greenhouse horticulture. Journal of Plant Nutrition 22, 1033-1048.

Soundararajan, P., Sivanesan, I., Jana, S., And Jeong, B. R. (2014). Influence of silicon supplementation on the growth and tolerance to high temperature in Salvia splendens. Horticulture, Environment, and Biotechnology, 55(4), 271-279.
TuRner, N. C. (1981). Techniques and experimental approaches for the measurement of plant water status. Plant and Soil, 58, 339-366.

Wang, S. Y., And Galletta, G. J. (1998). Foliar application of potassium silicate induces metabolic changes in strawberry plants. Journal of Plant Nutrition 21(1), 157-167.

Wróblewska, K., And DęBicz, R. (2011). The effect of silicon foliar application on the development of season ornamental plants. Part II: Argyranthemum frutescens 'Blazer Rose', Xerochrysum bracteatum 'Gold', Osteospermum ecklonis 'Grande Pink Blush' AND Gaura lindheimeri 'Corinas Choice'. Acta Agrobotanica, 64(4), 107-114.

Xu, C. X., And Liu, Y. L. (2015). Effects of silicon (Si) on growth, quality and ionic homeostasis of aloe under salt stress. South African Journal of Botany, 98, 26-36.

Yoshimura, K., Yabuta, Y., Ishikawa, T., And Shigeoka, S. (2000). Expression of spinach ascorbate peroxidase isoenzymes in response to oxidative stresses. Plant Physiology, 123, 223-234

Zahedi, S. M., Karimi, M., and Teixeira Da Silva, J. A. (2020a). The use of nanotechnology to increase quality and yield of fruit crops. Journal of the Science of Food and Agriculture, 100(1), 25-31.

Zahedi, S. M., Moharrami, F., Sarikhani, S., and Padervand, M. (2020b). Selenium and silica nanostructure-based recovery of strawberry plants subjected to drought stress. Scientific Reports, 10, 17672, doi: 10.1038/s41598-020-74273-9.

Zhang, L. X., Li, S. X., Zhang, H., and Liang, Z. S. (2007). Nitrogen rates and water stress effects on production, lipid peroxidation and antioxidative enzyme activities in two maize (Zea mays L.) genotypes. Journal of Agronomy and Crop Science, 193(6), 387-397.

Received: January 15, 2021; accepted: February 27, 2021 